Article

\title{
Temporal Variability of Sediments, Dissolved Solids and Dissolved Organic Matter Fluxes in the Congo River at Brazzaville/Kinshasa
}

\author{
Guy Dieudonne Moukandi N'kaya ${ }^{1, * \mathbb{C}}$, Didier Orange ${ }^{2, * \mathbb{D}}$, Sandra Murielle Bayonne Padou ${ }^{1}$, \\ Pankyes Datok ${ }^{3}$ and Alain Laraque ${ }^{4}$ \\ 1 LMEI/CUSI/ENSP/Marien N'gouabi University, BP 69 Brazzaville, Congo; bayonnemurielle91@gmail.com \\ 2 Eco\&Sols-UMR IRD/INRA/CIRAD/SupAgro-U. Montpellier-Place Viala, 34060 Montpellier, France \\ 3 Laboratoire écologie Fonctionnelle et Environment, Université de Toulouse, CNRS, INPT, UPS, \\ 31326 Castanet-Tolosan, Toulouse, France; pankyes-emmanuel.datok@univ-tlse3.fr \\ 4 UMR 5562 du CNRS, UR 234 de l'IRD—14, av. E. Belin, 31400 Toulouse, France; alain.laraque@ird.fr \\ * Correspondence: guymoukandi@yahoo.fr (G.D.M.N.); didier.orange@ird.fr (D.O.); \\ Tel.: +242-0665-996-14 (G.D.M.N. \& D.O.)
}

Received: 12 August 2020; Accepted: 20 August 2020; Published: 28 August 2020

\begin{abstract}
For three decades, the solid and dissolved fluxes of the Congo River have been regularly monitored on a monthly basis, despite 12 years of deficiencies (1994-2005). Two programs successively carried out these follow-ups: PEGI/GBF (1987-1993) and SO HYBAM (2006-2017), upstream and downstream, respectively, of the Malebo Pool near Brazzaville, the main hydrometric station of the Congo River. The objective of this study is to examine the temporal dynamic of TSS, TDS and DOC, to explore how these descriptors change over time. Comparison with the two time programs will shed more light on how these descriptors are related to discharge. Afterward, we then find a relationship between total TSS in the water column and that measured in surface for eventual estimation of TSS by remote sensing. In the last decade, compared to the PEGI/GBF period, the discharge of the Congo River was mainly marked by a $4 \%$ increase, leading to a significant change on TDS and DOC behaviors. The TSS was quite stable (from 8.2 and $9.3 \mathrm{t} \mathrm{km}^{-2} \mathrm{yr}^{-1}$ ) due to the low physical erosion well known in this region. The TDS concentrations decreased slightly, by a simple dilution effect. However, the mineral dissolved fluxes (from 11.6 and $10.1 \mathrm{t} \mathrm{km}^{-2} \mathrm{yr}^{-1}$ ) due to the chemical weathering and atmospheric inputs still predominate over the solid fluxes. Therefore, there was no radical change in the monthly geochemical regime of Congo River Basin (CRB) during these last 30 years. Contrariwise, the DOC concentration marking the biogeochemical processes significantly increased, from $9.0+/-3.0 \mathrm{mg} \mathrm{L}^{-1}$ to $12.7+/-5.0 \mathrm{mg} \mathrm{L}^{-1}$, due to more flooding events in the central part of the CRB. The change for the DOC fluxes is more relevant, with an increase of $45 \%$ between the two studied periods, from $11.1 \times 10^{6}$ to $16.2 \times 10^{6} \mathrm{t} \mathrm{yr}^{-1}$. This highlights the continuous and actual importance of the "Cuvette Centrale" in the heart of the CRB for dissolved organic matter transport by the Congo River.
\end{abstract}

Keywords: discharge; TSS; TDS; DOC; matter fluxes; Congo River

\section{Introduction}

Large tropical rivers have the largest matter transport capacity, due to having the largest greater volumes of water carried in their major bed [1,2]. Hence, they play a vital role in the global balance between terrestrial and marine ecosystems. Nevertheless, the processes that control the transport of sediment fluxes into the ocean are poorly understood and, because of the big size of the basins, it is often difficult to quantify these processes accurately over time [3]. 
For the Congo Basin, its sustainable socio-ecological management is an important concern related to global change. This is important because of its large size, and due to its position straddling the equator in a zone of fluctuating atmospheric exchanges along the Intertropical Convergence Zone (ITCZ). A better understanding of the evolution of its water flows, solids, and dissolved matter fluxes is still on the international scientific agenda.

The current quantification of solid and dissolved fluxes in the large Congo River basin $\left(3.7 \times 10^{6} \mathrm{~km}^{2}\right)$, which covers the main part of the central African rainforest, remains poorly understood due to the insufficiency of contemporary in situ measurements. The first measurements of Total Suspended Sediment (TSS) and Total Dissolved Solid (TDS) were carried out during the first half of the 20th century at the main hydrological station of Brazzaville/Kinshsa (BZV/KIN). A majority of authors [4-15] presented TSS values with a relatively good convergence, between 20 and $40 \mathrm{mg} \mathrm{L}^{-1}$. For TDS it is similar, with values presented between 30 and $40 \mathrm{mg} \mathrm{L}^{-1}$ [5,11,12,14-21]. For Dissolved Organic Carbon (DOC), all the authors [13,14] found values between 8 and $10 \mathrm{mg} \mathrm{L}^{-1}$ for analysis carried out from 1982. For TSS and TDS, pre-1968 data is the result of less accurate sampling protocols and laboratory analyses, with samples that do not regularly cover the entire hydrological cycle. In the late 1980s and early 1990s, the French research institute ORSTOM (Office de Recherche Scientifique et Technique d'Outre-Mer) (now Institut de Recherche pour le Développement, IRD) with the Congolese DGRST (Direction Générale de la Recherche Scientifique) conducted two consecutive international research programs in the northern part of the Congo River Basin between Brazzaville (Congo) and Bangui (Central African Republic). These are part of the Great Basin Fluvial research operation (GBF) funded by PIRAT (Programme Interdisciplinaire de Recherche de biogéodynamique intertropicale périatlantique) and PEGI (Program for the Study of the Intertropical Geosphere) programs. The results obtained during these programs made it possible to specify the fluxes of particulate and dissolved solid and organic matters transported by the Congo River and to know precisely the seasonal and interannual variations [22-28]. After this period, and until the early 2000s, very few studies were done on this topic $[26,27,29]$. It is only since 2005 that the solid and dissolved fluxes of the Congo River at its main hydrometric station, Brazzaville/Kinshasa, have regularly been monitored at monthly time steps. This monitoring is done by the SO HYBAM (Observation Service of the geodynamic, hydrological and biogeochemical controls of erosion/alteration of materials in the basins of the Amazon, Orinoco and Congo) program (SOH) with the collaboration of Marien Ngouabi University of Brazzaville [30]. The first results were published by Laraque et al. (2013) [31]. At last, recent works [32-36] have quantified transport fluxes using different methods, underlining the complexity of this large basin.

The objective of this study is to examine the temporal dynamic of TSS, TDS and DOC, to explore how these descriptors change over time. Comparison with the two time programs will shed more light on how these descriptors are related to discharge (i.e., hysteresis response). Afterward, we then find a relationship between total TSS in the water column and that measured at the surface for eventual estimation of TSS by remote sensing. Moreover, in this study, taking into account the insignificant surface area of the Malebo Pool compared to that of the Congo Basin, we postulate that the annual flow balances of the Congo River upstream and downstream remain similar. Even if on a seasonal scale, one can expect a low-intensity alternation of roles of sediment sink or source according to the different phases of the hydrological cycle.

\section{Materials and Methods}

\subsection{Study Area and Sampling Stations}

The Congo River is the longest river in Africa after the Nile, and the largest river in Africa in terms of water discharge and basin size (respectively 40,500 $\mathrm{m}^{3} \mathrm{~s}^{-1}$ and $3.7 \times 10^{6} \mathrm{~km}^{2}$ ), second only to the Amazon River at the global level. The Congo River streambed forms a broad curve that crosses the equator twice (Figure 1a). This provides a very regular hydrogram (with a discharge coefficient of seasonal variation of 1.77), where the discharge inputs of the tributaries of the northern 
hemisphere (e.g., Ubangi, Sangha Rivers) and south (e.g., Kasai River) succeed and complement each other. The hydrological regime of the Congo River is bimodal, typical of equatorial ones, with a main flood from November to January and a secondary flood from April to June. Its basin extends between the parallels $9^{\circ} \mathrm{N}$ and $14^{\circ} \mathrm{S}$ and the meridians $11^{\circ} \mathrm{E}$ and $34^{\circ} \mathrm{E}$, with an approximately concentric shape around the Congolese Cuvette, as well as in terms of its relief, its geology, its climate and its vegetation cover (Figure 1a-c). The Congo River Basin (CRB) is a central depression already described by Laraque et al. (2009) [28]. Around the equator, the CRB covers an area of 3,659,900 $\mathrm{km}^{2}$ at the hydrological station of BZV/KIN, which control $98 \%$ of its total area $\left(3,730,700 \mathrm{~km}^{2}\right)$, with an annual river flow of 40,500 $\mathrm{m}^{3} \mathrm{~s}^{-1}$ (for the period 1903-2017) [37]. In general, as pointed out by Hughes et al. (2001) [32], the CRB is essentially composed of Precambrian magmatic and metamorphic crystalline rocks with rare carbonate and evaporite rocks [33,38-40], while the central basin is composed of Quaternary alluvial deposits and clastic sedimentary rocks (Figure 1b) [41].

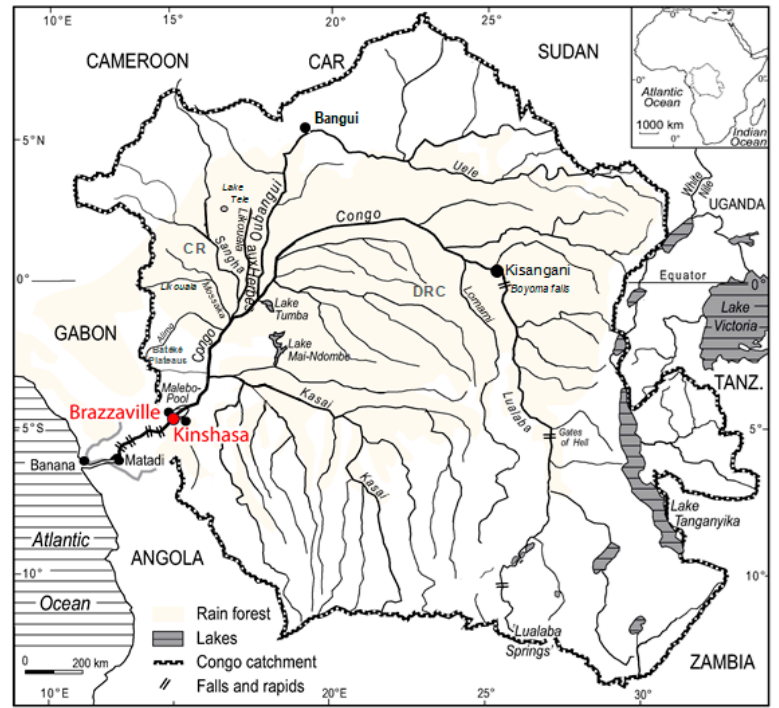

(a)

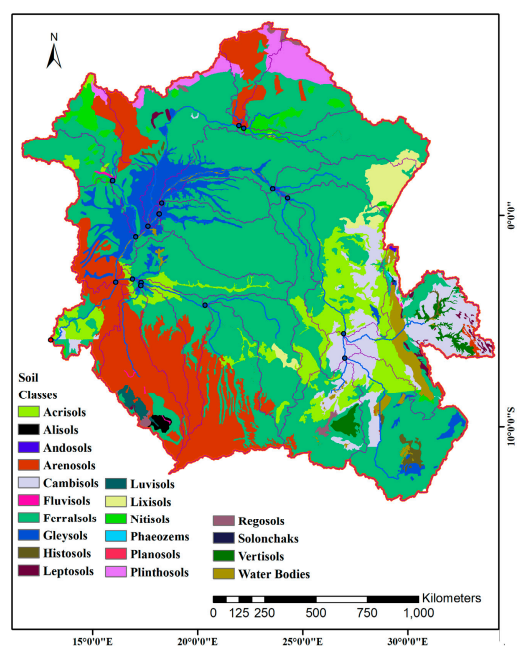

(c)

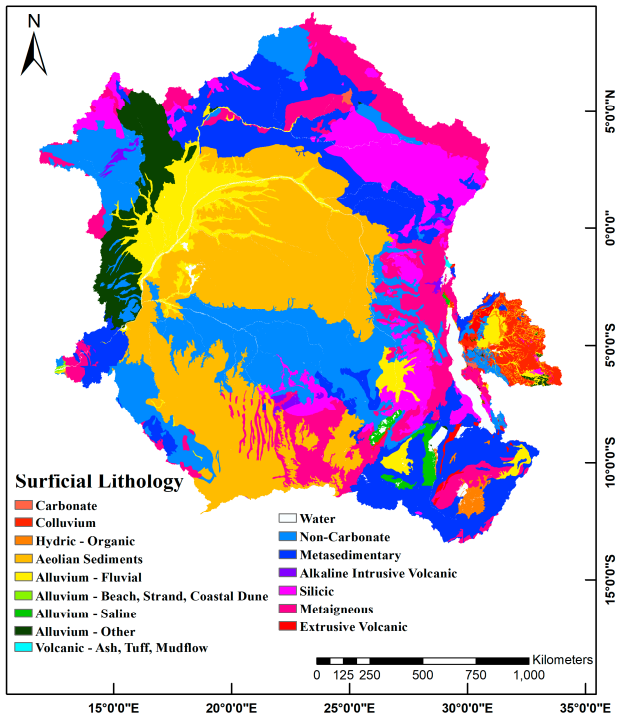

(b)

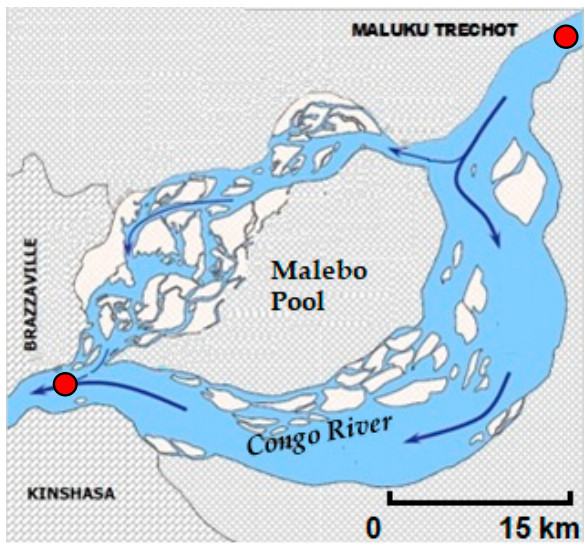

(d)

Figure 1. Introduction to the study site: (a) Overview of the Congo River Basin (adapted from Runge, 2007 [42]), (b) geology, (c) soil, and (d) Malebo Pool; the 2 dots represent the sampling station of the PEGI/GBF program in the upper part, and the sampling station of the SO/HYBAM program in the lower part. 
The main branch of the Congo River originates from the borders of Zambia and the DRC, near the basin of the Zambezi River, south of the Katanga Plateau (in the vicinity of the village of Musofi). The upper Congo River is named Lualaba upstream to Kisangani at the place of the Boyoma Falls (ex. Stanley falls). Downstream Kisangani the Congo River runs across the "Cuvette Centrale" covered with swamps, floating meadows, and equatorial rain forest, which is partially flooded during flood with very rare areas of dry land. Watered by 1600 to $1800 \mathrm{~mm}_{\text {year }}{ }^{-1}$ [43], this central basin consists of fluvial, clayey or sandy quaternary alluviums belonging to the Andosols class (Figure 1c), with watercourses divided in very sinuous ways, sometimes anastomosed, and often linked together by numerous natural or constructed channels favoring the flooding of the plains, as has been described by Laraque et al. (1998) [44]. There are major lakes such as Lake Tumba and Lake Maï Ndombe, which are very shallow (3-8 m), that extend over more than $3000 \mathrm{~km}^{2}$ on the left bank of the Congo River [45], and Lac Télé, which has an elliptical shape, covering $23 \mathrm{~km}^{2}$, located on the right bank of the Congo River [44]. In the northern part of the basin, the Congo River receives the Ubangui River, then downstream the Likouala aux Herbes, the Sangha and the Likouala-Mossaka rivers. The south part of this zone is representative of equatorial forest surrounded in the North by the large woody and grassy savannah from the Ubangui basin, a typical vegetation of the Sudanese climate [46].

Arriving in its last section, the Congo River collects the Batéké Rivers (Alima, Nkéni and Léfini), which drain the sandy-sandstone geological layers of the Batéké Plateau (arenosols), covered with grassy savanna and not forest (Figure 1c). These Batéké Rivers flow in deep valleys, and represent a hydrological paradox in this region, as stressed by Laraque et al. (1998) [47]. Their monthly discharges are very regular and contrast with the aridity of the vegetation cover [48]. In this region, the average annual rainfall is high $(1900 \mathrm{~mm})$ and the almost stable hydrological regimes do not reflect a well-marked dry season from June to August, due to the groundwater behavior [47].

Just after the Léfini, the Kasai River flows into the Congo River, where it contributes its share of organic, solid and dissolved matter.

Finally, the Congo River reaches the Malebo Pool, a vast depression about $30 \mathrm{~km}$ in diameter, where large sand banks emerge in the low water period (Figure 1d). This river section does not receive any important tributaries. The two gauging stations for liquid, solid and dissolved fluxes of this study are located upstream and downstream of this depression.

Before reaching the Ocean, the Congo River crosses the succession of Livingstone rapids, which prohibit any sea connection for boat transport, unlike most other major river basins on the planet [28].

\subsection{Sampling and Analytical Measurements}

Before describing the methodology, we should discuss the representativeness of the two sampling stations. Indeed, the monthly samples were taken at the Maluku Trechot station for the PEGI/GBF period and at the Brazzaville/Kinshasa station (BZV/KIN) for the SOH period. These two stations, separated by less than $30 \mathrm{~km}$ (Figure 1d), have the same climatic characteristics. This anastomosed river section, called the Malebo Pool, has no tributaries to impact the discharge. The morphology of the riverbed with sand islands have not changed during the last 40 years (no extension of islands and no reduction of anastomosed channels). Moreover, taking into account the insignificant surface area of the Malebo Pool compared to that of the Congo Basin, we assumed that this local geomorphological shape does not impact the Congo River annual fluxes.

The sampling time step for the two studied periods is monthly. The descriptive parameters of water quality (temperature $\mathrm{T}^{\circ} \mathrm{C}$, electrical conductivity $\mathrm{EC}, \mathrm{pH}$ ) were measured in situ using pre-calibrated electrodes. The TDS mineral concentrations have been measured according to the protocols described in Sondag et al. (1995) [23], Laraque et al. (2013) [31], http://www.so-hybam.org/ index.php/fre/Techniques/Analyses-de-laboratoire [30], and summarized in Figure 2.

During the PEGI/GBF program (1987-1993), TSS concentration was measured through a water sampling of 20 liters taken at five points along a central vertical line of the Congo River cross section at the Maluku Trechot station (upper part of the Pool Malebo), then sieved with a porosity of $62 \mu \mathrm{m}$ to 
get the sand particles. Next, one aliquot of 1 liter was filtered through $0.45 \mu \mathrm{m}$ cellulose acetate filter paper previously weighed in dry condition. After filtration, the filter paper was placed in an oven at a temperature of $105^{\circ} \mathrm{C}$ for 24 hours. After leaving the oven, the filter paper is kept in a desiccator before being weighed again. The weight in excess of that which was initially weighed before heating represents the total suspended sediment (TSS) in $\mathrm{mg} \mathrm{L}^{-1}$.

For the SOH program (2006-2017), each water sample was taken once at 30-50 cm below the surface of the central vertical line of the Congo River cross section at the Brazzaville/Kinshasa station. Water samples were collected and filtered the same day in the laboratory using pre-measured 0.45 cellulose acetate filter paper previously weighed in dry condition. To determine the Total Suspended Solid (TSS), 500 milliliters were filtered onto pre-weighed $0.45 \mu \mathrm{m}$ cellulose acetate filter paper under the same conditions as for the PEGI/GBF program.

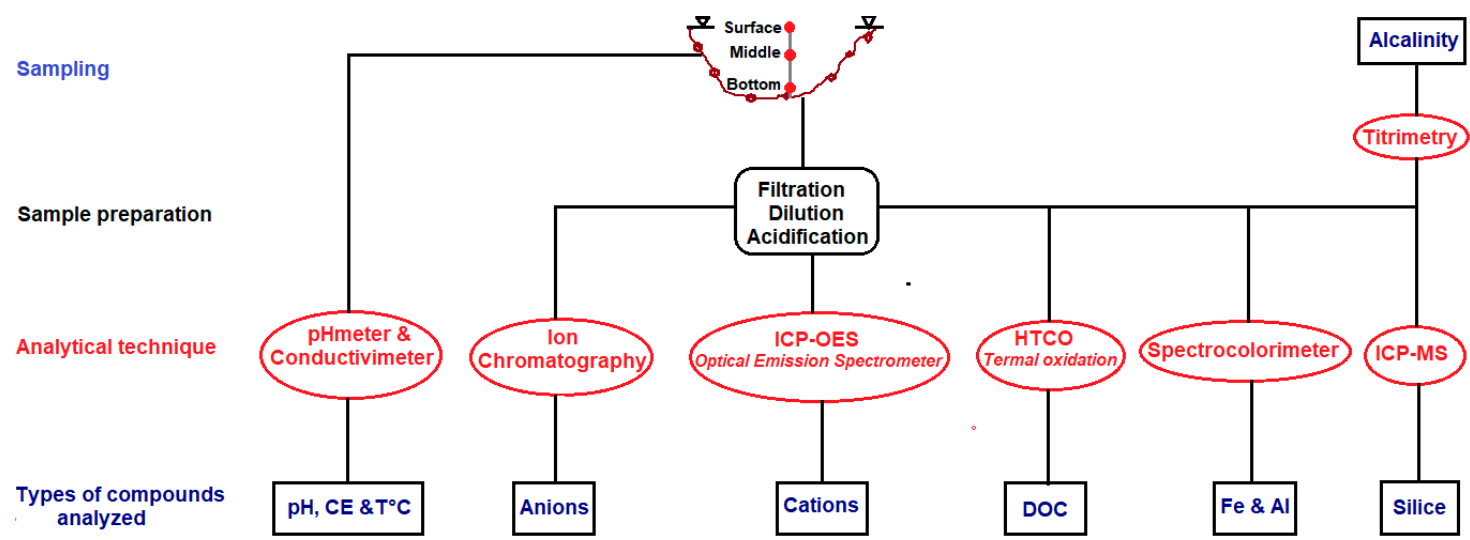

Figure 2. Protocols for the chemical analyses of descriptive water quality parameters (temperature $\mathrm{T}^{\circ} \mathrm{C}$, electrical conductivity EC, $\mathrm{pH}$ and TDS).

DOC was analyzed with the same protocol for PEGI/GBF and SOH programs, such as that described by Seyler et al. (2006) [27]. A water sample of 1 liter was taken in the center of the river cross section in sterilized containers. After homogenization, precise volumes of water were filtered through pre-heated and pre-weighed $0.70 \mu \mathrm{m}$ Whatman GFF fiberglass filters under reduced pressure to separate dissolved and particulate matter. The water fractions passing through the filter were acidified on a board with ultrapure $\mathrm{H}_{3} \mathrm{PO}_{4}$ and analyzed in the laboratory by high-temperature catalytic oxidation method (HTCO) using a Shimadzu TOC-5OOO Instrument to determine DOC concentrations (Figure 2).

\subsection{Statistical Analysis}

Different statistical analyses (means, standard deviation and coefficient of variation) were done in the Minitab software [49] and calculations of the monthly fluxes of dissolved and solid elements using the freeware software HYDRACCESS [30]. The sample concentration of the day is estimated to be the monthly concentration $\left(C_{m} \mathrm{mg} \mathrm{L}^{-1}\right)$. Then, the monthly fluxes $\left(\mathrm{kg} \mathrm{s}^{-1}\right)$ were calculated by multiplying the monthly concentration with the monthly discharge $\left(Q_{m} \mathrm{~m}^{3} \mathrm{~s}^{-1}\right)$, according to

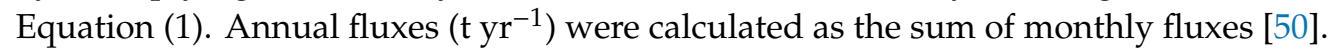

$$
\text { Flux }=K \sum_{m=1}^{12} C_{m} \times Q_{m}
$$

where $K$ is the unit conversion factor taking into account the period of interpolation between measured data and the units in which the fluxes will be expressed. 
To control the relative behavior of the TSS, TDS and DOC in relationship with the two studied periods, we propose to examine the hysteresis curves in relation to the monthly discharge. A study on the distribution of TSS along the central vertical line of sampling has been carried out since 2013 at the BZV/KIN measurement section.

\section{Results}

\subsection{Temporal Dynamic of Discharges, TSS, TDS and DOC Concentrations}

The evolution of the monthly discharge between the two studied periods is quite similar (Figure 3a). The two curves are quite parallel, with a slight increase of $4 \%$ for the recent period. The interannual average is $38,080 \mathrm{~m}^{3} \mathrm{~s}^{-1}$ and $39,660 \mathrm{~m}^{3} \mathrm{~s}^{-1}$ respectively for PEGI/GBF period and SOH period (Figure $3 \mathrm{~b}$ ), with a similar standard deviation (Table 1). The PEGI/GBF period belong to the driest interannual hydroclimatic period.

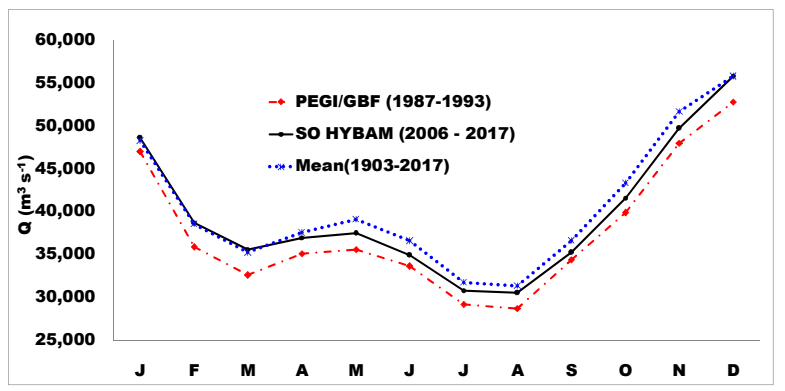

(a)

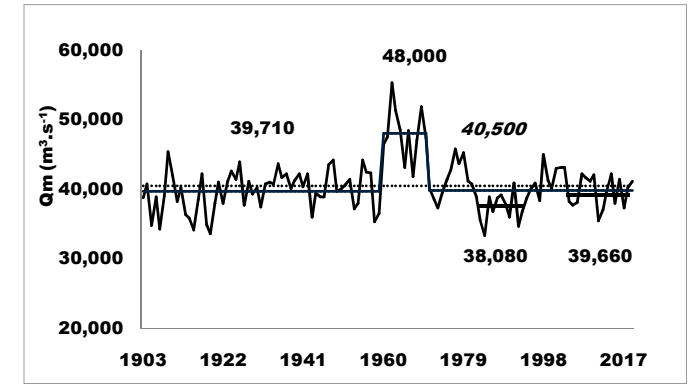

(b)

Figure 3. (a) Evolution of monthly river discharge related to the two studied periods and the interannual period (1903-2017). (b) Interannual variation of annual Congo River discharges (period 1903-2017).

Table 1. Interannual yearly discharge $(\mathrm{Qy})$ and surface water quality parameters (temperature, $\mathrm{pH}$, electrical conductivity, $\mathrm{SiO}_{2}$, total dissolved solid (TDS) concentrations, dissolved organic carbon (DOC) concentrations, total suspended solid (TSS) concentrations, and total matter (TOTAL = TDS + DOC + TSS) for the Congo River Outlet, calculated for the two studied periods (1987-1993 and 2006-2017).

\begin{tabular}{|c|c|c|c|c|c|c|c|c|}
\hline \multirow[b]{2}{*}{ Parameters \& Units } & \multicolumn{4}{|c|}{ PEGI/GBF (1987-1993) } & \multicolumn{4}{|c|}{ SOH (2006-2017) } \\
\hline & Mean \pm Std & Max & Min & Max/Min & Mean \pm Std & Max & Min & Max/Min \\
\hline Qy $\left(\mathrm{m}^{3} \mathrm{~s}^{-1}\right)$ & $38,080 \pm 8.46$ & 61,400 & 24,000 & 3.5 & $39,660 \pm 8.70$ & 61,330 & 22,710 & 2.7 \\
\hline $\mathrm{pH}$ & $6.7 \pm 0.5$ & 8.4 & 5.7 & 1.5 & $6.0 \pm 0.7$ & 8.9 & 5.1 & 1.8 \\
\hline $\mathrm{EC}\left(\mu \mathrm{s} \mathrm{cm}-1\right.$ at $\left.25^{\circ} \mathrm{C}\right)$ & $36.6 \pm 6.7$ & 48.4 & 22.0 & 2.2 & $28.4 \pm 4.98$ & 36.0 & 20.0 & 1.8 \\
\hline $\mathrm{SiO}_{2}$ & $9.6 \pm 1.1$ & 15.0 & 7.2 & 2.1 & $10.5 \pm 1.1$ & 14.4 & 5.7 & 2.5 \\
\hline $\operatorname{TDS}\left(\mathrm{mg} \mathrm{L}^{-1}\right)$ & $36.5 \pm 5.4$ & 48.9 & 23.0 & 2.1 & $31.1 \pm 3.8$ & 39.5 & 18.2 & 2.2 \\
\hline $\mathrm{DOC}\left(\mathrm{mg} \mathrm{L}^{-1}\right)$ & $* 9.9 \pm 3.0$ & * 17.6 & * 6.2 & 2.8 & $12.7 \pm 5.0$ & 29.3 & 5.2 & 5.6 \\
\hline TOTAL $\left(\mathrm{mg} \mathrm{L}^{-1}\right)$ & 71.7 & - & - & - & 71.0 & - & - & - \\
\hline
\end{tabular}

Std: Standard deviation. ${ }^{*}$ These are the values of Seyler et al. (2006) [27] and Coynel et al. (2006) [26] for the period 1990-1993.

Figure 4 shows the monthly variation of discharge Qm and concentrations of TSS, TDS and DOC from 1987 to 2017. The descriptive parameters of the water quality are quite similar, only that we notice more acidic waters (from 6.7 to 6.0) with a weaker conductivity (from $36.6 \mu \mathrm{S} \mathrm{cm}^{-1}$ to $28.4 \mu \mathrm{S} \mathrm{cm}-1$ ) and a higher annual concentration in DOC for the recent period. DOC increased from $9.9 \mathrm{mg} \mathrm{L}^{-1}$ to $12.7 \mathrm{mg} \mathrm{L}^{-1}$, a significant increase of $28 \%$.

The total matter transported (TOTAL $=$ TSS + TDS + DOC) did not change between the two studied periods, around $71.3 \mathrm{mg} \mathrm{L}^{-1}$, with $37 \%$ TSS $\left(26.3 \mathrm{mg} \mathrm{L}^{-1}\right)$ and $63 \%$ of total dissolved matter $(\mathrm{TDM}=\mathrm{TDS}+\mathrm{DOC})\left(45 \mathrm{mg} \mathrm{L}^{-1}\right)($ Table 1$)$. However, the dissolved balance between mineral and 
organic matter changed. For the more recent $\mathrm{SOH}$ period, DOC concentrations represent $30 \%$ of dissolved concentrations, while it was only $21 \%$ during the last PEGI period.

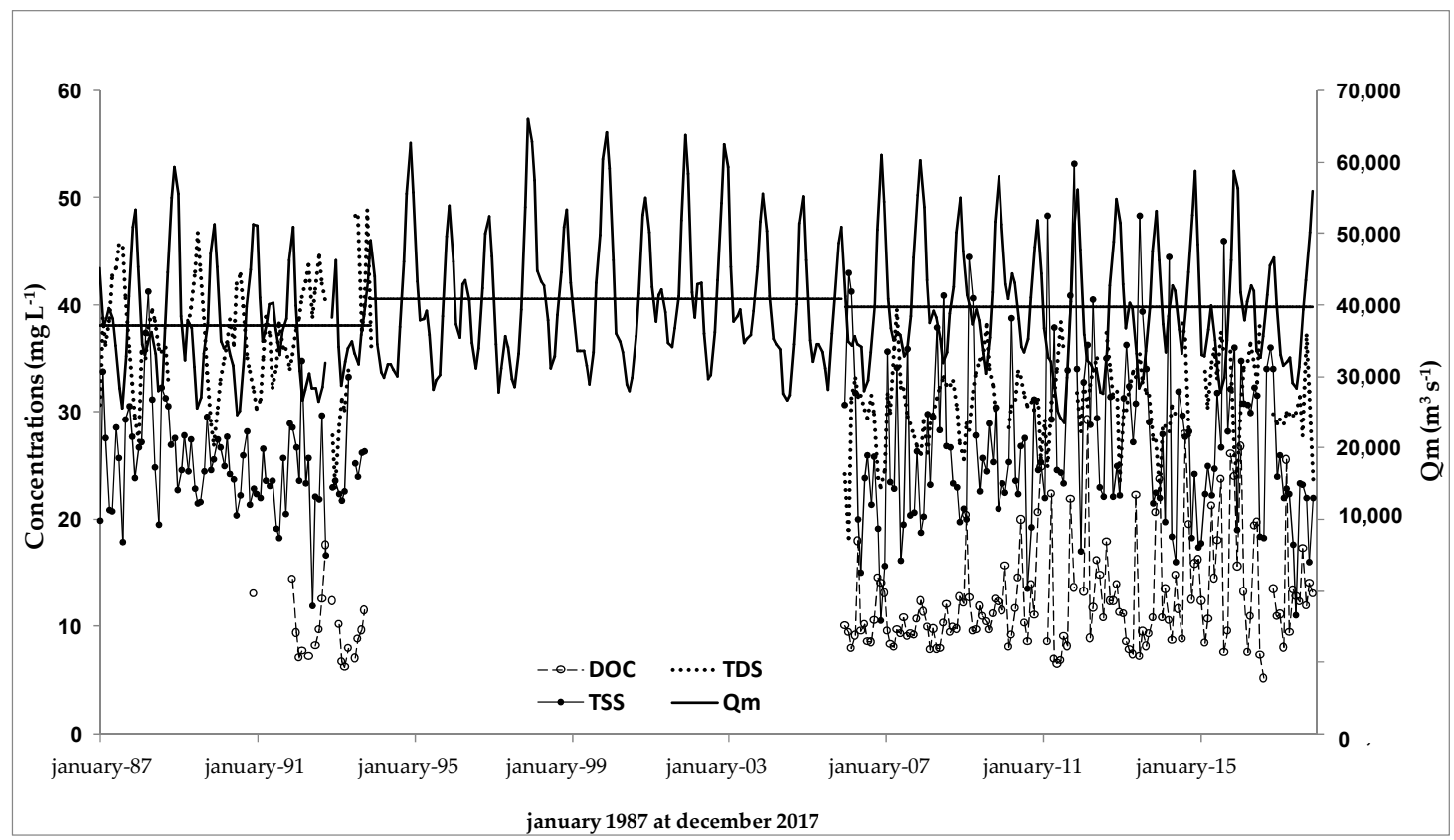

Figure 4. The interannual variation of monthly discharge $(\mathrm{Qm})$ and concentrations of total suspended sediment (TSS), total dissolved solids (TDS) and dissolved organic carbon (DOC) of the Congo River at Maluku Trechot for 1987-1993 (PEGI/GBF program) and at Brazzaville/Kinshasa for the 2006-2017 period (SOH program). Monthly DOC values are from December 1990 to October 1993 and during the 2006-2017 period).

The measured TSS concentrations between the two periods are quite similar, with a slight increase from 25.3 to $27.2 \mathrm{mg} \mathrm{L}^{-1}$. The variability during the recent period is more important.

Then we conclude that only the dissolved concentrations significantly changed between the two studied periods, with a decrease of TDS and an increase of DOC.

\subsection{Monthly Concentrations and Fluxes}

The main well-known characteristic of the Congo River at its outlet is the regular monthly variation of its discharge, with a variation coefficient of 1.8 for the two studied periods (Table 2). TSS and TDS concentrations have a lower variation coefficient $(<1.5)$; only DOC concentration showed a variation of 2.4 during the period 1987-1993, but its variation during the recent period is similar to that of TDS, at around 1.4 (Table 2).

Monthly TSS concentrations are linked to the monthly discharge, with two small peaks during the year, one in March, just before the first rise in water of the Congo River, and a second in August-September, just at the beginning of the main water rise of the Congo River (Figure 5). However, TDS and DOC concentrations do not follow this pattern. During the earlier studied period (1987-1993), the monthly TDS concentrations described a one-peak curve along the year: the peak of TDS load is in August (with $42.2 \mathrm{mg} \mathrm{L}^{-1}$ ) during the base flow period. The monthly DOC curve follows a delay, describing also a one-peak curve with the maximum in November (with $34.1 \mathrm{mg} \mathrm{L}^{-1}$ ), just one month before the discharge peak flow (Figure 5). 
Table 2. Interannual monthly discharges (Qm) and interannual monthly concentrations of total suspended sediment (TSS), total dissolved solid (TDS), dissolved organic carbon, total dissolved matter (TDM = TDS + DOC) and DOC/TDM percentage, at the Congo River Outlet, respectively, calculated for the two studied periods (1987-1993 and 2006-2017).

\begin{tabular}{|c|c|c|c|c|c|c|c|c|c|c|c|c|}
\hline \multicolumn{7}{|c|}{ PEGI/GBF Program (1987-1993) } & \multicolumn{6}{|c|}{ SO HYBAM Program (2006-2017) } \\
\hline Parameters & Qm & TSS & TDS & DOC & TDM & DOC/TDM & Qm & TSS & TDS & DOC & TDM & DOC/TDM \\
\hline Unit & $\mathrm{m}^{3} \mathrm{~s}^{-1}$ & $\mathrm{mg} \mathrm{L}^{-1}$ & $\mathrm{mg} \mathrm{L}^{-1}$ & $\mathrm{mg} \mathrm{L}^{-1}$ & $\mathrm{mg} \mathrm{L}^{-1}$ & $\%$ & $\mathrm{~m}^{3} \mathrm{~s}^{-1}$ & $\mathrm{mg} \mathrm{L}^{-1}$ & $\mathrm{mg} \mathrm{L}^{-1}$ & $\mathrm{mg} \mathrm{L}^{-1}$ & $\mathrm{mg} \mathrm{L}^{-1}$ & $\%$ \\
\hline Jan. & 46,979 & 24.95 & 29.53 & 9.40 & 38.93 & 24 & 48,597 & 21.24 & 24.92 & 14.60 & 39.52 & 37 \\
\hline Febr. & 35,841 & 25.94 & 33.37 & 8.65 & 42.02 & 21 & 38,696 & 28.78 & 29.54 & 14.01 & 43.55 & 32 \\
\hline March & 32,566 & 27.87 & 35.55 & 7.23 & 42.77 & 17 & 35,580 & 31.17 & 29.89 & 11.10 & 40.99 & 27 \\
\hline April & 35,073 & 26.78 & 37.57 & 6.20 & 43.77 & 14 & 36,942 & 31.78 & 31.69 & 11.28 & 42.97 & 26 \\
\hline May & 35,557 & 26.12 & 39.07 & 7.60 & 46.67 & 16 & 37,447 & 28.08 & 33.19 & 11.17 & 44.37 & 25 \\
\hline June & 33,606 & 24.02 & 39.31 & 7.50 & 46.81 & 16 & 34,868 & 23.34 & 33.06 & 13.58 & 46.65 & 29 \\
\hline July & 29,137 & 22.36 & 41.56 & 7.63 & 49.18 & 16 & 30,778 & 28.39 & 32.95 & 12.99 & 45.94 & 28 \\
\hline Aug. & 28,663 & 23.17 & 42.22 & 9.25 & 51.47 & 18 & 30,478 & 27.10 & 34.35 & 10.92 & 45.27 & 24 \\
\hline Sept. & 34,383 & 26.66 & 39.84 & 11.13 & 50.96 & 22 & 35,198 & 26.97 & 33.05 & 11.74 & 44.79 & 26 \\
\hline Oct. & 39,854 & 26.07 & 36.26 & 14.55 & 50.81 & 29 & 41,592 & 27.23 & 32.18 & 12.73 & 44.92 & 28 \\
\hline Nov. & 48,014 & 25.18 & 34.06 & 15.00 & 49.06 & 31 & 49,743 & 27.33 & 29.66 & 13.48 & 43.15 & 31 \\
\hline Dec. & 52,774 & 25.22 & 32.15 & 13.30 & 45.45 & 29 & 55,855 & 24.15 & 26.57 & 15.72 & 42.28 & 37 \\
\hline Mean \pm Std & $37,704 \pm 7.678$ & $25.36 \pm 1.57$ & $36.71 \pm 3.92$ & $9.79 \pm 3.01$ & $46.49 \pm 4.01$ & $21 \pm 6$ & $39,648 \pm 7.883$ & $27.13 \pm 3.03$ & $30.92 \pm 2.89$ & $12.78 \pm 1.56$ & $43.70 \pm 2.07$ & $29 \pm 4$ \\
\hline Max. & 52774 & 27.87 & 42.22 & 15.00 & 51.47 & 31 & 55,855 & 31.78 & 34.35 & 15.72 & 46.65 & 37 \\
\hline Min. & 28663 & 22.36 & 29.53 & 6.20 & 38.93 & 14 & 30,478 & 21.24 & 24.92 & 10.92 & 39.52 & 24 \\
\hline Max./Min. & 1.84 & 1.25 & 1.43 & 2.42 & 1.32 & 2.21 & 1.83 & 1.50 & 1.38 & 1.44 & 1.18 & 1.54 \\
\hline
\end{tabular}




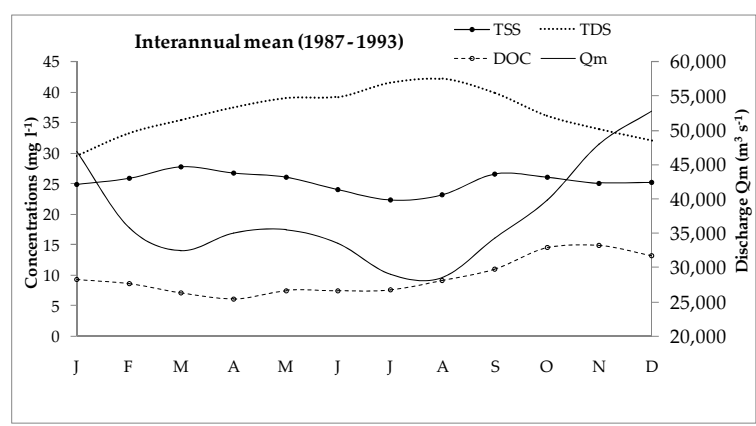

(a)

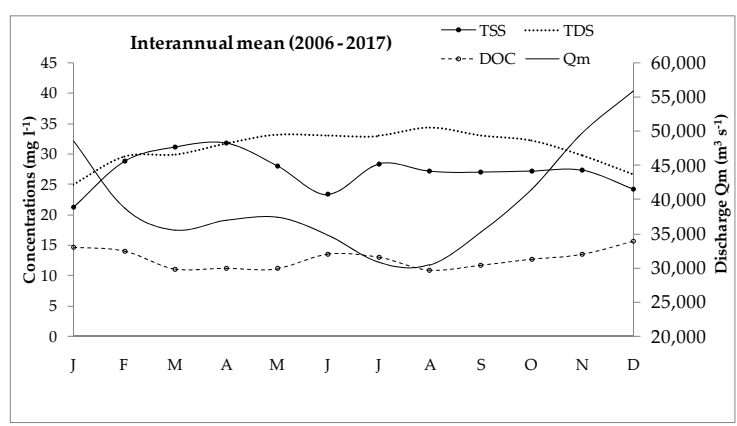

(b)

Figure 5. The annual variation of interannual monthly concentrations of total suspended sediment (TSS), total dissolved solid (TDS) and dissolved organic carbon (DOC) (on left axis) at the Congo River Outlet related to the interannual monthly discharge (Q) (on right axis), for (a) the PEGI period (1987-1993) and (b) the SOH period (2006-2017).

During the recent period (2006-2017), the monthly TDS concentrations are lower, while the monthly DOC concentrations are higher and quite similar throughout the year, in a range of 10 to 15 $\mathrm{mg} \mathrm{L}^{-1}$. The monthly increase of DOC is more significant during the first part of the year, from January to July, which corresponds to the discharge recession period of the Congo River. Consequently, the ratio between DOC and TDM (= DOC + TDS) has significant seasonal changes, from $14 \%$ to $31 \%$ in 1987-1993, and from $24 \%$ to $37 \%$ in 2006-2017. On average, the DOC represents $29 \%$ of the total dissolved concentration during the recent period, against $21 \%$ during the previous studied period (Table 2).

The monthly evolution of TSS, TDS and DOC fluxes follow exactly what was observed for their concentrations (Figure 6). The seasonal variations in suspended and dissolved matter fluxes (TSS, TDS and DOC) are similar to the discharge for the two studied periods. The maxima are observed during the peak flow of the Congo River; the minima correspond to the low-water period.

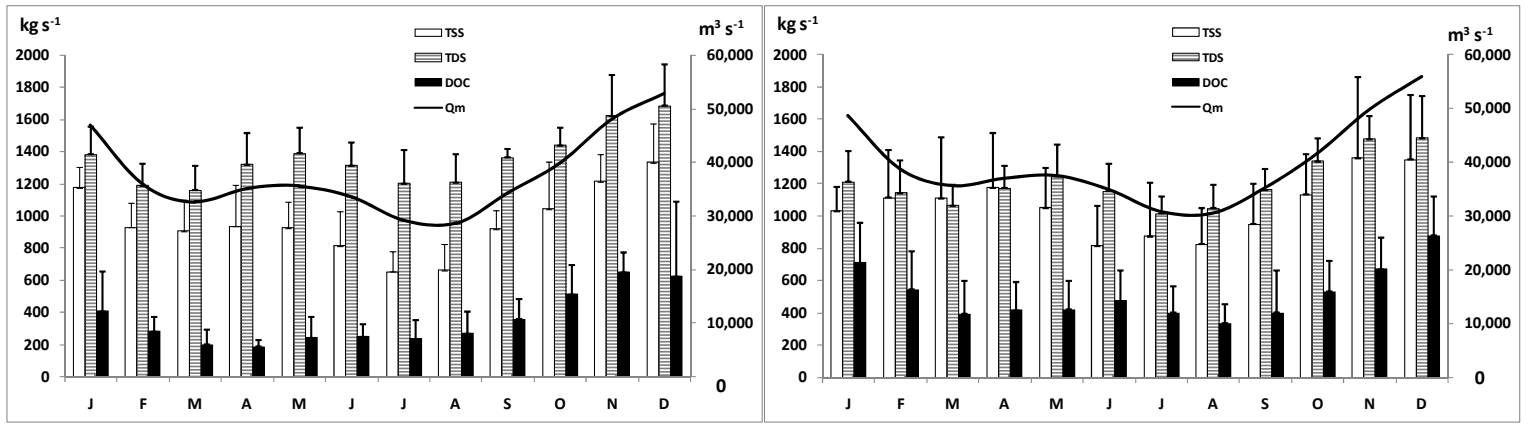

(a)

(b)

Figure 6. The annual variation of interannual monthly fluxes of total suspended sediment (TSS), total dissolved solid (TDS) and dissolved organic carbon (DOC) at the Congo River outlet, related to the interannual monthly discharge (Qm), from (a) 1987-1993, and (b) 2006-2017.

\subsection{Annual Fluxes}

The interannual total matter fluxes (dissolved and particulate) at the Congo River Outlet are quite similar between the two studied periods, 1987-1993 and 2006-2017. During the PEGI/GBF period, the interannual total matter flux was $84.0 \times 10^{6} \mathrm{t} \mathrm{yr}^{-1}$ versus $87.9 \times 10^{6} \mathrm{t} \mathrm{yr}^{-1}$ during the recent period (Table 3). TSS fluxes have increased by $11 \%$, respectively $30.2 \times 10^{6}$ to $33.6 \times 10^{6} \mathrm{t} \mathrm{yr}^{-1}$ between old

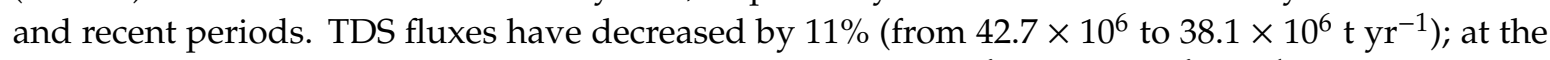
opposite the DOC fluxes have increased by $46 \%$ (from $11.1 \times 10^{6}$ to $15.1 \times 10^{6} \mathrm{t} \mathrm{yr}^{-1}$ ). 
Table 3. Interannual mean fluxes and specific fluxes of water (Qs), total suspended sediment (TSS), total dissolved solid (TDS), dissolved organic carbon, total dissolved matter (TDM = TDS + DOC) and total transported matter (TOTAL = TSS + TDM), for the two studied periods, 1987-1993 and 2006-2017.

\begin{tabular}{|c|c|c|c|c|c|c|c|c|}
\hline $\begin{array}{c}\text { Mean } \\
\text { Inter-Annual } \\
\text { Fluxes }\end{array}$ & $\begin{array}{c}\text { Basin Area } \\
\text { at Station } \\
10^{6} \mathrm{~km}^{2}\end{array}$ & $\begin{array}{c}\text { Total Basin } \\
\text { Area } \\
10^{6} \mathbf{k m}^{2} \\
\end{array}$ & $\underset{10^{9} \mathrm{~m}^{3} \mathrm{yr}^{-1}}{\mathrm{Qm}}$ & $\begin{array}{c}\text { TSS } \\
10^{6} \mathrm{t} \mathrm{yr}^{-1}\end{array}$ & $\begin{array}{c}\text { TDS } \\
10^{6} \mathrm{t} \mathrm{yr}^{-1}\end{array}$ & $\begin{array}{c}\text { DOC } \\
10^{6} \mathrm{tyr}^{-1}\end{array}$ & $\begin{array}{c}\text { TDM } \\
10^{6} \mathrm{t} \mathrm{yr}^{-1}\end{array}$ & $\begin{array}{c}\text { TOTAL } \\
10^{6} \mathrm{t} \mathrm{yr}^{-1}\end{array}$ \\
\hline 1987-1993 & 3.6 & 3.7 & 1189 & 30.2 & 42.7 & 11.1 & 53.8 & $84.0 \pm 15.9$ \\
\hline $\begin{array}{l}\text { Specific } \\
\text { Fluxes }\end{array}$ & & & 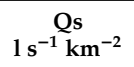 & $\begin{array}{c}\text { TSS } \\
t k^{-2} \mathrm{yr}^{-1}\end{array}$ & 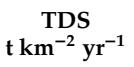 & $\underset{t k^{-2} \mathrm{yr}^{-1}}{\text { DOC }}$ & $\underset{t k^{-2} \mathrm{yr}^{-1}}{\text { TDM }}$ & $\begin{array}{c}\text { TOTAL } \\
\mathbf{t} \mathbf{k m}^{-2} \mathbf{y r}^{-1}\end{array}$ \\
\hline 1987-1993 & & & 10.3 & 8.4 & 11.9 & 3.1 & 14.9 & $23.3 \pm 4.4$ \\
\hline
\end{tabular}

Of course, this change has significantly impacted the water quality of the Congo River at its mouth outlet (Figure 7). In the 1990s, DOC flux represented 13\% of the total matter transported with 51\% of TDS and 36\% of TSS. In addition, today, DOC part has increased to close to $19 \%$, with a TDS flux decrease and quite similar with TSS flux, representing respectively $43 \%$ in TDS and $38 \%$ in TSS (Table 3 and Figure 7).

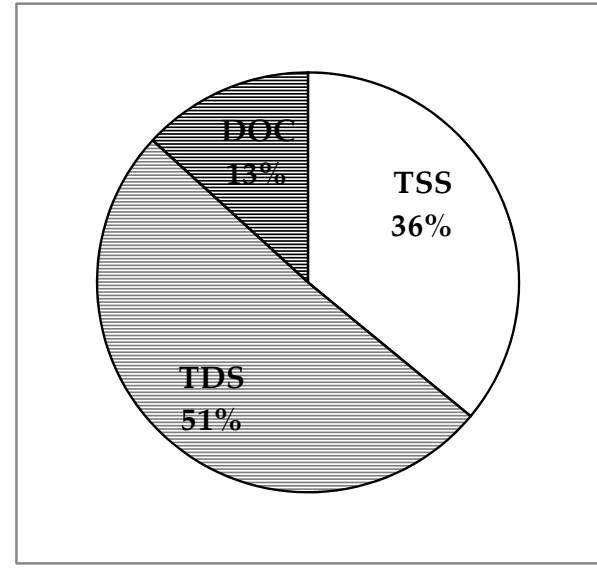

(a)

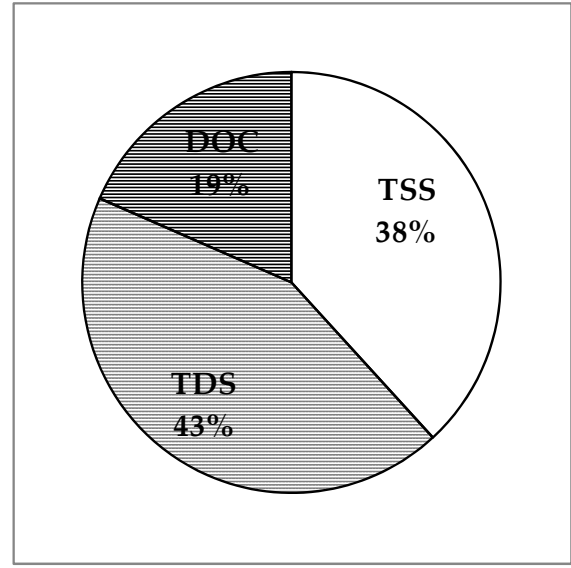

(b)

Figure 7. Percentage contribution in fluxes of total suspended sediment (TSS), total dissolved solid (TDS), and dissolved organic carbon (DOC) of the total matter fluxes transported by the Congo River at its mouth outlet for: (a) the 1987-1993 period, and (b) the 2006-2017 period.

Finally, the measured change between the two studied periods is very important if we consider the specific temporal flux of DOC. Indeed, the DOC flux changed from 3.1 to $4.5 \mathrm{t} \mathrm{km}^{-2} \mathrm{yr}^{-1}$; a strong increase of around $45 \%$.

\subsection{Concentrations of Matter versus Water Discharges}

The concentrations versus discharges at a monthly time step described a classical C-Q hysteresis; this could be used as a descriptor of biogeochemical behavior of the river basin [51-53]. For the two periods, TSS, TDS and DOC monthly concentrations at the Congo River Outlet show a classic double hysteresis, linked to its bimodal river regime related to the hydrological cycle of the river which begins at the end of August (Figure 8). For all the variables, the main hysteresis takes place from November to January, during the main flood of the river, and the second from March to June during the second small peak flow in the spring period. 

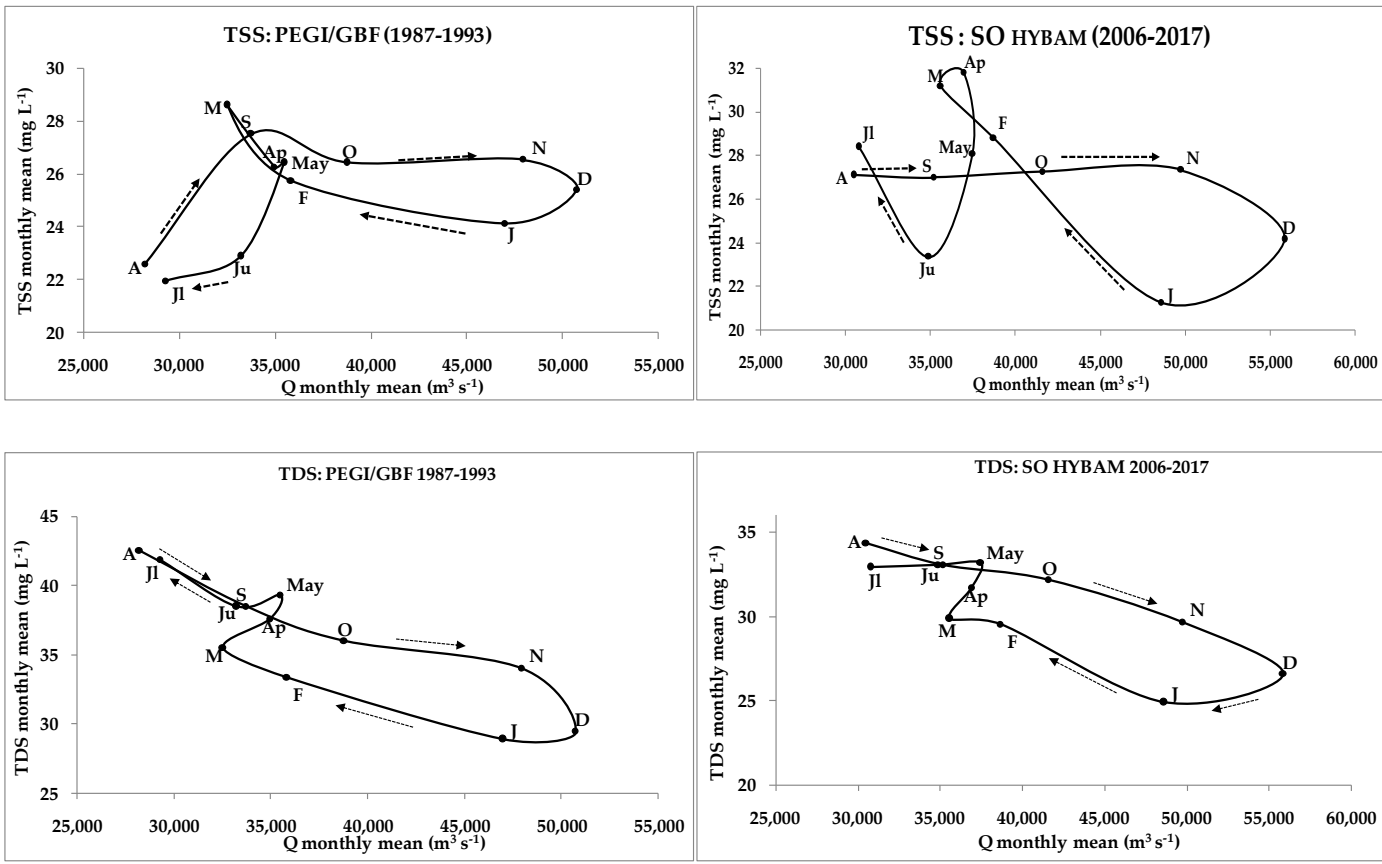

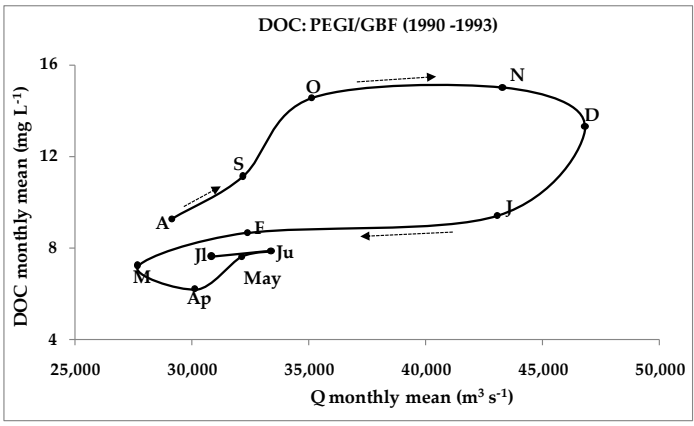

(a)

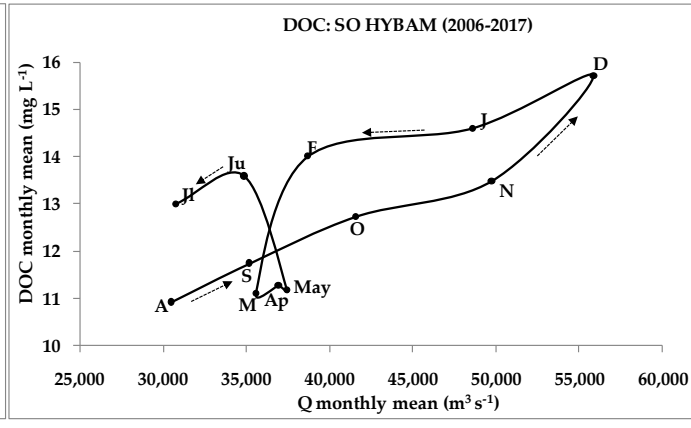

(b)

Figure 8. Hysteresis curves between monthly mean TSS, TDS and DOC concentrations versus mean monthly discharges at the Congo River Outlet: (a) 1987-1993 period, and (b) 2006-2017 period.

TSS and TDS C-Q curves describe a clockwise loop for both studied periods. It describes a classic dilution pattern of concentration by the discharge. Relatively stable, the TSS concentrations show a slight decrease in January for both studied periods (between 24 to $26 \mathrm{mg} \mathrm{L}^{-1}$ for 1987-1993 and between 22 to $26 \mathrm{mg} \mathrm{L}^{-1}$ for 2006-2017). The TDS concentrations show a dilution effect during the flood, underlined by the inclination of the loop for the two studied periods (between 30 to $38 \mathrm{mg} \mathrm{L}^{-1}$ for the 1987-1993 and between 25 to $32 \mathrm{mg} \mathrm{L}^{-1}$ for 2006-2017).

However, the DOC C-Q hysteresis behavior seems to have changed between the two studied periods: from a classic dilution pattern in 1987-1993, it seems to take on a flushing pattern during the recent period. Indeed, the rotation pattern of the DOC-Q hysteresis for the current period is counterclockwise, while that of the PEGI period was clockwise.

\subsection{Spatio-Temporal Distribution of TSS Central Sampling Vertical Line}

The distribution of TSS along a vertical line in the middle of the river cross section was measured monthly from 2013 to 2017 at the BZV/KIN station (Figure 9). During the recent period, the TSS concentration at the water surface is always higher except in May and June. Based on three points of measurement along the vertical (from 0 to $11 \mathrm{~m}$ depth), a significant positive regression was established 
between the mean TSS vertical and the surface TSS concentration, with a regression coefficient of $\mathrm{R}^{2}=0.62$ (Figure 10).
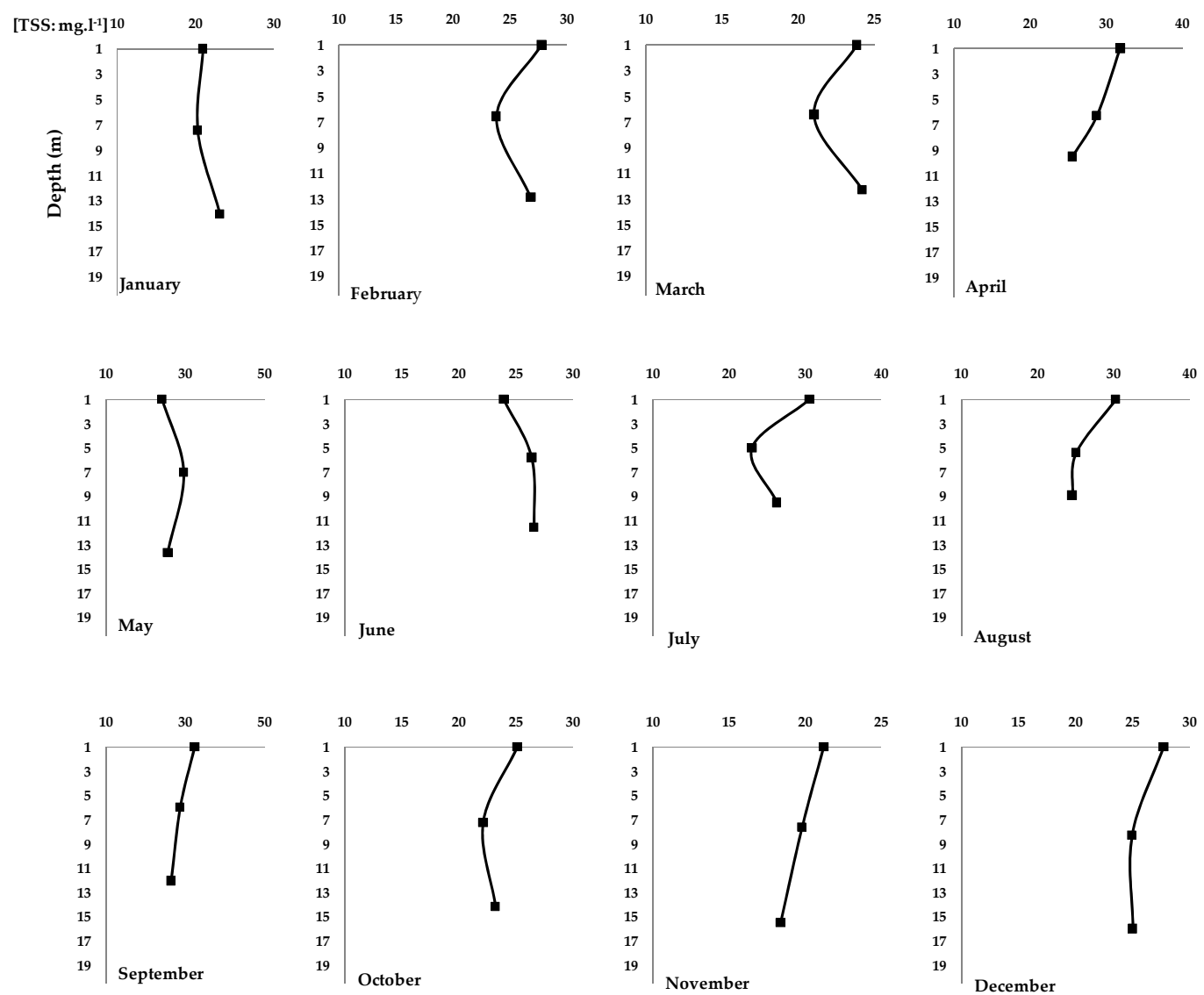

Figure 9. Spatial and temporal distribution of mean monthly TSS concentration (during the period January 2013-December 2017) at three point of the water column (Surface, Middle, Bottom). On the $\mathrm{x}$-axis are the TSS concentrations $\left(\mathrm{mg} \mathrm{L}^{-1}\right)$ and on the $\mathrm{y}$-axis the depth $(\mathrm{m})$.

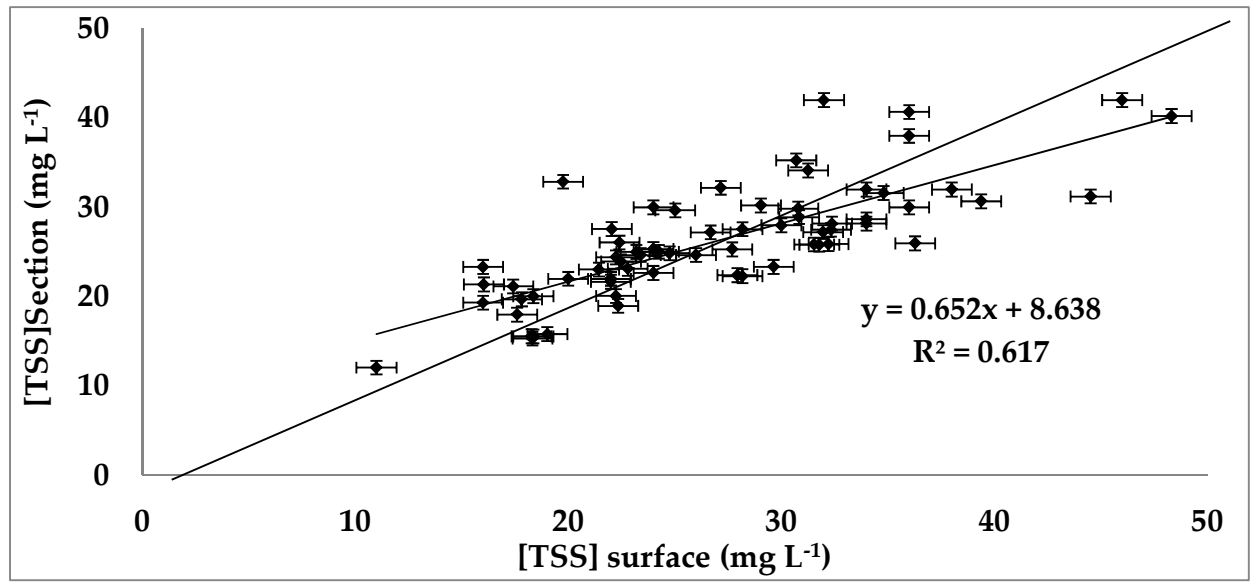

Figure 10. Average vertical TSS concentration versus surface TSS concentration for Congo River at BZV/KIN during SOH program.

\section{Discussion}

Based on the longest serial data records of the Congo River discharge at its outlet, from 1903 to 2017 , the yearly module of the Congo River at its main station is $40,500 \mathrm{~m}^{3} \mathrm{~s}^{-1}$. On this long temporal chronicle, the evolution of the flows during the two studied periods presents a hydroclimatic 
deficit for the PEGI period $\left(38,080 \mathrm{~m}^{3} \mathrm{~s}^{-1}\right)$ and a hydroclimatic normal stage for $\mathrm{SOH}\left(39,660 \mathrm{~m}^{3} \mathrm{~s}^{-1}\right)$. The Congo River discharge slightly increased by $4 \%$ for each month throughout the year (Figure 3a). The interannual mean TSS concentrations appear to be similar, from $25.3 \mathrm{mg} \mathrm{L}^{-1}$ in $1987-1993$ to $27.2 \mathrm{mg} \mathrm{L}^{-1}$ in 2006-2017 (Table 1). By consequence, the total suspended flux transported by the Congo River at its mouth is very stable between the two studied periods, from $30.2 \times 10^{6}$ to $33.6 \times 10^{6} \mathrm{t} \mathrm{yr}^{-1}$, which demonstrates no significant change on the specific erosion of the CRB, from 8.4 to $9.3 \mathrm{t} \mathrm{km}^{-2}$ $\mathrm{yr}^{-1}$ (Table 3). This small increase of 1 unit could be attributed to the small increase of the discharge and not at all from any anthropogenic impact on the forest cover.

These TSS values are similar to those obtained by Laraque et al. (2013) [31], who studied a shorter chronicle (2006-2010), and correspond to the same order of magnitude of erosion rates previously published and determined by different independent methods $[25,29,35,36,54,55]$. We note that a TSS flux of $31.2 \times 10^{6} \mathrm{t} \mathrm{yr}^{-1}$ was calculated by Gibbs (1967) [8].

Therefore, the Congo River Basin is particularly characterized by a very stable mechanical erosion along the last 30 years (from 1987 to 2017). In addition, based on the calculation of Gibbs (1967) [8], we might conclude that the erosion did not change from the 1960s. Compared to the major rivers of the planet, we confirm that the erosion on the CRB is very low. For instance, Amazon $\left(1509.3 \mathrm{t} \mathrm{km}^{-2}\right.$ $\left.\mathrm{yr}^{-1}\right)$ [56] and Orinoco $\left(88.5 \mathrm{t} \mathrm{km}^{-2} \mathrm{yr}^{-1}\right)$ [31] in South America, or Mekong $\left(625 \mathrm{t} \mathrm{km}^{-2} \mathrm{yr}^{-1}\right)$ [55] and Red River in Asia $\left(600 \mathrm{t} \mathrm{km}^{-2} \mathrm{yr}^{-1}\right)$ [57] have much higher values of specific erosion. Within the African continent, the Congo River is only ahead of the Senegal River, which has a specific degradation calculated over 9 years of $16.7 \mathrm{t} \mathrm{km}^{-2} \mathrm{yr}^{-1}$ [51].

In contrast, the total dissolved solid TDS transported by the Congo River at its mouth significantly changed in terms of concentrations (from $36.7+/-3.9 \mathrm{mg} \mathrm{L}^{-1}$ to $30.9+/-2.9 \mathrm{mg} \mathrm{L}^{-1}$ ) and fluxes (from $42.7 \times 10^{6}$ to $38.1 \times 10^{6} \mathrm{t} \mathrm{yr}^{-1}$ ) between the two studied periods. Throughout the year, the TDS concentrations are the lowest during the peak flow due to the classic dilution effect. The maximum occurs during the low flow in August. This scheme was observed from the fluxogram of the two studied periods. The decrease of $11 \%$ of TDS fluxes might be attributed partially to the increase of the discharge. On the other hand, the weak predominance in TDS could come from low cation concentrations in the lixiviation waters, as the soils appear to have already leached from most of their dissolved elements over time as underlined by Laraque et al. (1998b) [47]. If there were some specific point source of pollution due to the recent human land-use, the large amount of water volume transported by the Congo River is always efficient to dilute these human disruptions.

The specific chemical weathering decreased slightly on these last 30 years, from $11.9 \mathrm{t} \mathrm{km}^{-2} \mathrm{yr}^{-1}$ to $10.6 \mathrm{t} \mathrm{km}^{-2} \mathrm{yr}^{-1}$ (Table 3). These values of geochemical erosion range the CRB in thirtieth position worldwide and first position for Africa just before the Zambezi River [22].

These comparisons are indicative and deserve to be re-evaluated. Indeed, on the one hand, the methods of operation and calculation vary according to the authors and the periods of study, and do not always concern interannual averages, which moreover were not established at the same periods.

On the other hand, the specific dissolved fluxes calculated here are not corrected by atmospheric inputs, whose relative influence is all the more important as the water is not very polluted. Thus, for dissolved matter of Congo River, Nkounkou and Probst (1987) [21] estimate the atmospheric inputs at $34 \%$ of the TDS fluxes.

The change for the DOC fluxes is more relevant, with an increase of $45 \%$ between the two studied periods, from $9.0+/-3.0 \mathrm{mg} \mathrm{L}^{-1}$ to $12.7+/-5.0 \mathrm{mg} \mathrm{L}^{-1}$ in concentrations and from $11.1 \times 10^{6}$ to $16.2 \times 10^{6} \mathrm{t} \mathrm{yr}^{-1}$ in fluxes. These DOC concentrations are a little bit more important than the values published in early 1980s, with 8 to $10 \mathrm{mg} \mathrm{L}^{-1}[13,14]$. The dissolved organic carbon comes essentially from the Congolese basin, covered with a tropical forest flooded to semi-flooded depending on the hydrological cycle $[25,26,58,59]$ : the DOC concentration increases with the increase of the discharge. It is exactly the pathway observed during the period 1987-1993 (Figure 4). The DOC concentration increases in relation to the production of humic and fulvic acids from the central forest and swamps, which also causes a drop in $\mathrm{pH}[28,59]$, as shown in Table 1 . In the same way, a first previous study 
of DOC variations in the 1950s [60] suggested that the left bank tributaries strongly contribute to the supply of dissolved organic matter. This therefore confirms the scenario according to which during the period of high flow, the forest of the Congolese basin is flooded and brings large amounts of DOC through the tributaries of the left and right banks [44,47]. This natural framework of the Congolese basin functioning implies a decrease in the monthly DOC concentrations during the low flow, which we observed for the two periods studied, although with different amplitudes. During the recent period, the monthly DOC concentrations were more stable throughout the whole year, from 11 to $16 \mathrm{mg} \mathrm{L}^{-1}$ (Figure 4, Table 2).

The hysteresis features between concentrations and discharges describe a consistent bimodal pattern across the last 30 years for TSS and TDS, and not for DOC. In this study, we showed that there is remarkable stability in the forms and patterns of C-Q hysteresis for TSS and TDS concentrations versus the Congo River discharges, describing a bimodal clockwise loop. The hysteresis loop is double because of the bimodal regime of the river. DOC-Q hysteresis does not have this recurring characteristic, with either clockwise or counterclockwise bimodal shapes, respectively, in 1986-1993 and 2006-2017. This prevents their classification in a general model [52,53]. If we consider a still slow evolution of human activities inside the CRB [61], we may assume that the recent DOC change in the Congo River's fluxes should be attributed to the slight increase of the Congo River. This change may be due to the higher discharges in the SOH period compared to the PEGI/GBF period, leading to greater flooding of the Cuvette Centrale, which will therefore release more DOC.

Finally, the Total Dissolved Matter TDM (= TDS + DOC) is notably stable between the two studied periods, despite the $4 \%$ increase in flows. Interannual TDM fluxes remain relatively stable due to the reverse compensating effect of TDS and DOC, around $54 \times 10^{6} \mathrm{t} \mathrm{yr}^{-1}$ (i.e., $15 \mathrm{t} \mathrm{km}^{-2} \mathrm{yr}^{-1}$ ).

During a hydrological year, the Congo River in Brazzaville/Kinshasa benefits from hydro-sedimentary inputs from its various tributaries, which complement each other at its different phases; this may provide the small differences (from the single to only the double of the concentrations of TSS, TDS and DOC, similar to its monthly discharges).

Because of some recent results obtained in the Amazon and Orinoco basins [62-65] - two other large intertropical rivers-evaluating the river TSS fluxes based on remote sensing by river water colorimetry, we analyzed the TSS concentrations from January 2013 at three points of the central vertical line of the river cross section (Figure 9).

In general, for large rivers, the velocity gradients are reversed along the water column with respect to TSS concentrations (the discharge acting as a dilutant of the TSS concentration). In fact, near the riverbed, the water velocity is lower due to the friction effect, and the TSS concentrations are higher due to Stokes law. For the Congo River at BZV/KIN, we observed the opposite (Figure 9). The slightly higher concentrations of surface TSS are an unusual feature, and can be explained by two factors. On the one hand, (i) a narrowing of the river at the outlet of the Stanley Pool can favor the mixing of the TSS by funnel effect, and/or on the other hand, (ii) those TSS already not very concentrated (between 10 and $50 \mathrm{mg} \mathrm{L}^{-1}$ ) are probably mainly composed of low-density particles, which would facilitate their return to the surface.

As the TSS concentrations of the three sampling depths vary concomitantly (Figure 11), it is now possible, thanks to satellite remote sensing (Landsat 8 OLI and MODIS sensors), to evaluate the TSS concentration of the Congo waters, as was successfully carried out on the Orinoco, Amazon and Guyanese rivers [62-65]. The colorimetry of waters makes it possible to link their reflectance to their surface TSS concentration. In addition, the regression of Figure 10 makes it possible to estimate the average TSS concentration in the measuring section of the Congo River. Then, using the daily flows of the day of sampling, a TSS flow is obtained. 


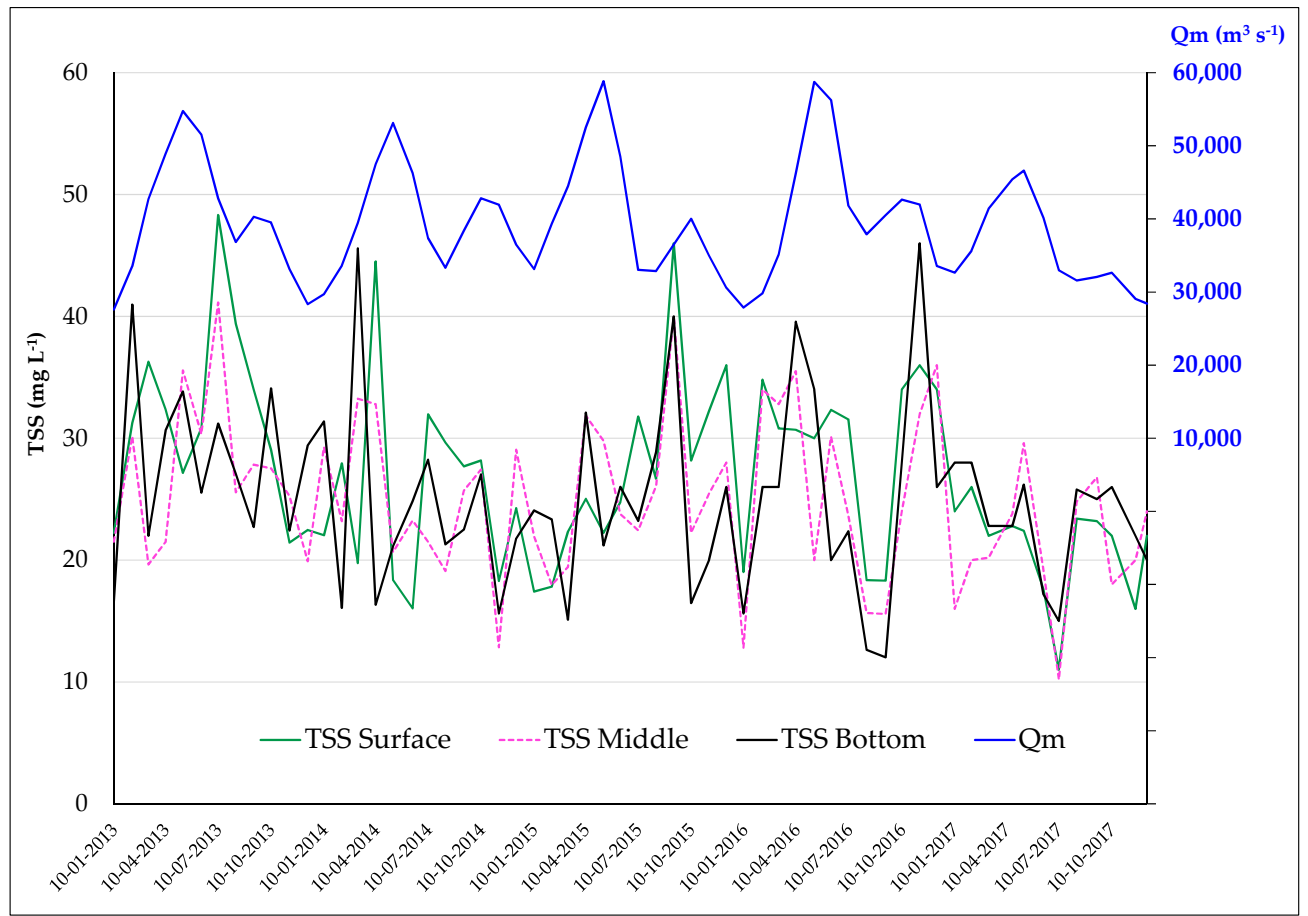

Figure 11. Temporal evolution of TSS sampled at different depths versus the hydrological cycle on Congo River at BZV/KIN section.

\section{Conclusions}

A comparison of TSS, TDS, DOC concentrations and fluxes of the Congo River at its mouth was made from two sets of in situ data (PEGI/BGF, period: 1987-1993 vs. SOH, period: 2006-2017). The results provide a general hydrological and biogeochemical explanation of the dynamics of TSS, TDS and DOC in the Congo River during the last 30 years.

Between these two studied periods, the Congo River discharge slightly increased by $4 \%$ and the interannual mean TSS concentrations appears to be similar. This confirms that the Congo River is showing little degradation compared to other of the world's major rivers. Contrariwise, the dissolved matter (mineral and organic) transported by the Congo River at its mouth significantly changed in concentrations and fluxes between the two studied periods. There is a decrease in TDS for the SOH period compared to the PEGI/GBF period. Throughout the hydrological cycle, TDS concentrations are lowest during peak flow, due to the classical dilution effect. The most observed change is the increase in DOC concentrations between the two study periods, because the higher discharge allows more intense flooding of the Cuvette Centrale, the main producer of organic matter in this vast basin. The increase in flooded area and in time of water residence in the flooded forest at the confluence between Congo and the tributaries of the Ubangui, Sangha, Likouala aux Herbes, Likouala Mossaka, Lake Tumba, Ruki may explain the increase in DOC contents $(+31 \%)$. Then the variations in flow rates between the two periods appear to be the predominant factors of the changes in concentrations and fluxes of the mineral and organic dissolved water components (TDS and DOC) of the Congo River at its mouth.

The monthly pattern of the classical C-Q hysteresis annual loop confirms this behavior. Due to the bimodal annual hydrological cycle of the Congo River at BZN/KIN, the bimodal pattern of hysteresis loop is recurrent, with a general clockwise rotation. However, during the current period, the DOC-Q hysteresis has changed to counterclockwise, highlighting the flooding impact of the Cuvette Centrale leaching more DOC.

Another highlight of this study is the relative homogeneity of the TSS along a vertical gradient studied in the middle of the BZV/KIN river cross-section. This relative homogeneity can be explained by the hydrodynamic characteristics of the section and by the composition and the density of the TSS. 
It should be interesting to assess the solid matter fluxes of the Congo River at its mouth through remote sensing techniques.

The relative stability of the hydro-sediments and bio-geochemical descriptors of the Congo River at BZV/KIN underlines the inertia of this large hydrographic basin straddling the equator, which remains dominated by its pristine character.

Finally, since the SO HYBAM period (2006-2017) presents an average inter-annual flow similar to that of the entire period of available flows since $1903\left(1250 \times 10^{9} \mathrm{~m}^{3} \mathrm{yr}^{-1}\right)$, one could consider that its material flows are representative of the average flow from Congo to BZV/KIN over the past 115 years, i.e., 33.6; 38.1; 16.2 and $87.9 \times 10^{6} \mathrm{t} \mathrm{yr}^{-1}$, respectively, for TSS, TDS, DOC and for its total exports of suspended and dissolved materials to the Atlantic Ocean. Its specific flows $\left(10.81 \mathrm{~s}^{-1} \mathrm{~km}^{-2}, 9.3\right.$ and $15.1 \mathrm{t} \mathrm{km}^{-2} \mathrm{yr}^{-1}$ ), respectively for Q, TSS, and TDM make it possible to compare this large intertropical watershed with its counterparts (e.g., Orinoco River: $37.91 \mathrm{~s}^{-1} \mathrm{~km}^{-2}, 88.5$ and $41.1 \mathrm{t} \mathrm{km}^{-2} \mathrm{yr}^{-1}$ [31]).

Author Contributions: Conceptualization, G.D.M.N. and A.L.; methodology, G.D.M.N., D.O. and P.D.; software, G.D.M.N. and S.M.B.P.; validation, D.O. and A.L.; formal analysis, G.D.M.N. and D.O.; data curation, A.L. and S.M.B.P.; writing—original draft preparation, G.D.M.N.; writing—review and editing, G.D.M.N., D.O., P.D. and A.L.; visualization, P.D., A.L. and D.O.; supervision, A.L.; project administration, G.D.M.N. and A.L.; funding acquisition, G.D.M.N. All authors have read and agreed to the published version of the manuscript.

Funding: This research was funded by AUF; grant number DRACGL-2019-4100" and "The APC" did not receive any funding.

Acknowledgments: Thanks go to the IRD through the SO HYBAM program and the GET Toulouse laboratory and team with the support of Marien Ngouabi University (UNMG) and Groupement d'Intérêt EconomiqueService Commun d'Entretien des Voies Navigable (GIE-SCEVN).

Conflicts of Interest: The authors declare no conflict of interest. The funders had no role in the design of the study; in the collection, analyses, or interpretation of data; in the writing of the manuscript, or in the decision to publish the results.

\section{References}

1. Zhu, Y.M.; Lu, X.X.; Zhou, Y. Suspended sediment flux modeling with artificial neural network: An example of the Longchuanjiang River in the upper Yangtze catchment, China. Geomorphology 2007, 84, 111-125. [CrossRef]

2. Syvitski, J.P.M.; Kettner, A.J.; Overeem, I.; Brakenridge, G.R. Latitudinal Controls on Siliciclastic Sediment Production and Transport. In Latitudinal Controls on Stratigraphic Models and Sedimentary Concepts; SEPM Special Publication: Tulsa, OK, USA, 2017; pp. 1-15. [CrossRef]

3. Molliex, S.; Kettner, A.J.; Laurent, D.; Droz, L.; Marsset, T.; Laraque, A.; Rabineau, M.; Moukandi N'Kaya, G.D. Simulating sediment supply from the Congo watershed over the last 155 ka. Quarter. Sci. Rev. 2019, 203, 38-55. [CrossRef]

4. Van Mierlo, J.G. Le mécanisme des alluvions du Congo. Annls Ass Ingrs Éc Gand 1926, 5, 349-354.

5. Spronck, R. Mesures hydrographiques dans la région divagante de bief maritime du fleuve Congo. Mém. Inst. Roy. Colon, Sect. Sci. Technol. 1941, 3, 56.

6. Devroey, E. Le Bassin Hydrographique Congolais, Spécialement Celui du Bief Maritime; Institut Royal Colonial Belge: Brussels, Belgium, 1941; p. 172.

7. Nedeco (Netherlands Engineering Company). River Studies, Niger and Benué; North Holland Publ. Co.: Amsterdam, The Netherlands, 1959.

8. Gibbs, R.J. Amazon river - environmental factors that control Iits dissolved and suspended load. Science 1967, 156, 1203-1232. [CrossRef]

9. Van der Linden, M.J.H. Reactions between Acids and Leaf Liter. Premier Colloque Int. Biodegradation et Humification. Ph.D. Thesis, University of Nancy, Pont-à-Mousson, France, 1975.

10. Eisma, D.; Kalf, J.; Vandergaast, S.J. Suspended Matter in the Zaire Estuary and the Adjacent Atlantic Ocean. Neth. J. Sea Res. 1978, 12, 382-406. [CrossRef]

11. Meybeck, M. Note on e1ementa1 contents of the Zaïre River. Neth. J. Sea Res. 1978, 12, 293-295. [CrossRef]

12. Molinier, M. Note sur les débits et la qualité des eaux du Congo à Brazzaville. Cah. ORSTOM Sér. Hydrol. $1979,16,55-66$. 
13. Eisma, D. Suspended matter as a carrier for pollutants in estuaries and the sea. In Marine Environmental pollution, 2. Mining and Dumping; Geyer, R.A., Ed.; Elsevier: Amsterdam, The Netherlands, 1981; Volume 27, pp. 281-295.

14. Mouzeo, K. Transport Particulaire Actuel du Fleuve Congo et de Quelques Affluents; Enregistrement Quaternaire Dans L'éventail Détritique Profond (Sédimentologie, Mineralogie et Géochimie). Ph.D. Thesis, Université de Perpignan, Perpignan, France, 1986.

15. Olivry, J.C.; Bricquet, J.P.; Thiébaux, J.P.; Sigha-Nkamdjou, L. Transport de matière sur les grands fleuves des régions intertropicales: Les premiers résultats des mesures de flux particulaires sur le bassin du fleuve Congo. In Sediment Budgets; AISH: Porto-Alegre, Brazil, 1988; pp. 509-521.

16. Symoens, J.J. La minéralisation des eaux naturelles. Résultats scientifiques. Explo. hydrobiol. Bassin du Lac Bangwelo et du Luapula 1968, 2, 1-199.

17. Meybeck, M. Concentrations des eaux fluviales en éléments majeurs et apports en solution aux océans. Rev. Géol. Dyn. Géogr. Phys. 1979, 21, 215-246.

18. Deronde, L.; Symoens, J.J. L'exportation des éléments dominants du bassin du fleuve Zaïre: Une réévaluation. Ann. Limnol-Int. J. Limnol. 1980, 16, 183-188. [CrossRef]

19. Moukolo, N.; Laraque, A.; Olivry, J.-C.; Bricquet, J.P. Transport en solution et en suspension par le fleuve Congo (Zaïre) et ses principaux affluents de la rive droite. Hydrol. Sci. J. 1993, 38, 133-145. [CrossRef]

20. Meybeck, M. Carbon, nitrogen and phosphorus transport by world rivers. Am. J. Sci. 1982, 282, 401-450. [CrossRef]

21. Nkounkou, R.; Probst, J.L. Hydrology and geochemistry of the Congo River system. In Transport of Carbon and Minerals in Major World Rivers; Degens, E.T., Ed.; SCOPE/UNEP Sond, Part 4; Mitt. Geol-palaont. Insti. Univ.: Hambourg, Germany, 1987; Volume 64, pp. 483-508.

22. Laraque, A.; Briquet, J.P.; Olivry, J.C.; Berthelot, M. Transport solides et dissous du fleuve Congo (bilan de six années d'observation. In Grands Bassins Fluviaux Périatlantiques: Congo, Niger, Amazone; Olivry, J.C., Boulegue, J., Eds.; IRD: Marseille, France, 1995; pp. 133-145.

23. Sondag, F.; Laraque, A.; Riandey, C. Chimie des eaux du fleuve Congo à Brazzaville et de l'Oubangui à Bangui (années 1988 à 1992). In Grands Bassins Fluviaux Périatlantiques: Congo, Niger, Amazone; Olivry, J.C., Boulegue, J., Eds.; IRD: Marseille, France, 1995; pp. 121-131.

24. Olivry, J.C.; Briquet, J.P.; Laraque, A.; Guyot, J.L.; Bourges, J.; Roche, M.A. Flux liquides, dissous et particulaires de deux grands bassins intertropicaux: Le Congo à Brazzaville et le Rio Madeira à Villabella. In Grands Bassins Fluviaux Périatlantiques: Congo, Niger, Amazone; Olivry, J.C., Boulegue, J., Eds.; IRD: Marseille, France, 1995; pp. 345-355.

25. Gaillardet, J.; Dupré, B.; Allègre, C.J. A global chemical budget applied to the Congo Basin Rivers: Erosion rates and continental crust composition. Geochem. Cosmochim. Acta 1995, 59, 3469-3485. [CrossRef]

26. Coynel, A.; Seyler, P.; Etcheber, H.; Meybeck, M.; Orange, D. Spatial and seasonal dynamics of total suspended sediment and organic carbon species in the Congo River. Glob. Biogeochem. Cycles 2006, 19, GB4019. [CrossRef]

27. Seyler, P.; Coynel, A.; Moreira-Turcq, P.; Etcheber, H.; Colas, C.; Orange, D.; Bricquet, J.P.; Laraque, A.; Guyot, J.L.; Meybeck, M. Organic carbon transported by the equatorial rivers: Example of Zaire-Congo and Amazon Rivers. In Soil Erosion and Carbon Dynamics; Roose, E.J., Lal, R., Feller, C., Barthes, B., Stewart, B.A., Eds.; CRC Press: Boca Raton, FL, USA, 2006; Volume 15, pp. 255-274.

28. Laraque, A.; Bricquet, J.P.; Pandi, A.; Olivry, J.C. A review of material transport by the Congo River and its tributaries. Hydrol. Process. 2009, 23, 3216-3224. [CrossRef]

29. Leturmy, P.; Lucazeau, F.; Brigaud, F. Dynamic interactions between the Gulf of Guinea passive margin and the Congo River drainage basin: 1. Morphology and mass balance. J. Geophys. Res. 2003, 108, 2383. [CrossRef]

30. Hybam. So-Hybam Amazon Basin Water Resources Observation Serve. Available online: http://www.sohybam.org (accessed on 27 September 2019).

31. Laraque, A.; Castellanos, B.; Steiger, J.; Lopez, J.L.; Pandi, A.; Rodriguez, M.; Rosales, J.; Adèle, G.; Perez, J.; Lagane, C. A comparison of the suspended and dissolved matter dynamics of two large inter-tropical rivers draining into the Atlantic Ocean: The Congo and the Orinoco. Hydrol. Process. 2013, 1-18. [CrossRef] 
32. Hughes, H.J.; Sondag, F.; Cocquyt, C.; Laraque, A.; Pandi, A.; André, L.; Cardinal, D. Effect of seasonal biogenic silica variations on dissolved silicon fluxes and isotopic signatures in the Congo River. Limnol. Oceanogr. 2011, 56, 551-561. [CrossRef]

33. Mann, P.J.; Spencer, R.G.M.; Dinga, B.J.; Poulsen, J.R.; Hernes, P.J.; Fiske, G.; Salter, M.E.; Wang, Z.A.; Hoering, K.A.; Six, J.; et al. The biogeochemistry of carbon across a gradient of streams and rivers within the Congo Basin. J. Geophys. Res. Biogeosci. 2014, 119, 687-702. [CrossRef]

34. Spencer, R.G.M.; Hernes, P.J.; Dinga, B.; Wabakanghanzi, J.N.; Drake, T.W.; Six, J. Origins, seasonality, and fluxes of organic matter in the Congo River. Glob. Biogeochem. Cycles 2016, 30. [CrossRef]

35. Guillocheau, F.; Galmier, V.; Robin, C. Source to Sink study of the Congo system since 40 Myr: A measurement ratio between mechanical and chemical erosion. In Proceedings of the Source to Sink: A Long Term Perspective of Sediment Budgets and Sources Characterization, Rennes, France, 30 November-2 December 2016.

36. Latrubesse, E.M.; Arima, E.Y.; Dunne, T.; Park, E.; Baker, V.R.; d'Horta, F.M.; Wight, C.; Wittmann, F.; Zuanon, J.; Baker, P.A.; et al. Damming the rivers of the Amazon basin. Nature 2017, 546, 363-369. [CrossRef] [PubMed]

37. Moukandi N'kaya, G.D.; Laraque, A.; Paturel, J.M.; Gulemvuga, G.; Mahé, G.; Tshimanga Muamba, R. A new look at hydrology in the Congo Basin, based on the study of multi-decadal chronicles. In Congo Basin Hydrology, Climate, and Biogeochemistry: A Foundation for the Future; Alsdorf, D., Tshimanga Muamba, R., Moukandi N'kaya, G.D., Eds.; AGU, John Wiley \& Sons Inc.: Malden, MA, USA, 2021; Unpublished work.

38. Giresse, P. La succession des sédimentations dans les bassins marins et continentaux du Congo depuis le début du Mésozoïque. Sci. Géol. Bull. Strasbg. 1982, 35, 183-206.

39. Négrel, P.; Allegre, C.J.; Dupre, B.; Lewin, E. Erosion sources determined by inversion of major and trace element ratios and strontium isotopic ratios in river water: The Congo Basin case. Earth Planet. Sci. Lett. 1993, 120, 59-76. [CrossRef]

40. Giresse, P. Mesozoic-Cenozoic history of the Congo basin. J. Afr. Earth Sci. 2005, 43, 301-315. [CrossRef]

41. Dürr, H.H.; Meybeck, M.; Dürr, S.H. Lithologic composition of the Earth's continental surfaces derived from a new digital map emphasizing riverine material transfer. Glob. Biogeochem. Cycles 2005, 19, GB4S10. [CrossRef]

42. Runge, J. The Congo River, Central Africa. In Large Rivers: Geomorphology and Management; Gupta, A., Ed.; Wiley and Sons: London, UK, 2007; pp. 293-309.

43. BRLi. Développement et Mise en Place de L'outil de Modélisation et D'allocation des Ressources en eau du Bassin $d u$ Congo; Rapport technique de construction et de calage du modèle; CICOS: Kinshasa, Republic of the Congo, 2016.

44. Laraque, A.; Pouyaud, B.; Rocchia, R.; Robin, R.; Chaffaut, I.; Moutsambote, J.M.; Maziezoula, B.; Censier, C.; Albouy, Y.; Elenga, H.; et al. Origin and function of a closed depression in equatorial humid zones: The lake Tele in north Congo. J. Hydrol. 1998, 207, 236-253. [CrossRef]

45. Wei, X.; Sauvage, S.; Le, T.P.Q.; Ouillon, S.; Orange, D.; Vinh, V.D.; Sanchez-Perez, J.M. A modeling approach to diagnose the impacts of global changes on discharge and suspended sediment concentration within the Red River Basin. Water 2019, 11, 958. [CrossRef]

46. Wesselink, A.; Orange, D.; Feizouré, C.T.; Randriamiarisoa. Les régimes hydroclimatiques et hydrologiques d'un bassin versant de type tropical humide: L'Oubangui (République Centrafricaine). In L'hydrologie Tropicale: Géosciences et Outil Pour le Développement: Mélanges à la Mémoire de Jean Rodier; Chevallier, P., Pouyaud, B., Eds.; IAHS: Wallingford, UK, 1996; Volume 238, pp. 179-194.

47. Laraque, A.; Mietton, M.; Olivry, J.C.; Pandi, A. Impact of lithological and vegetal covers on flow discharge and water quality of Congolese tributaries from the Congo River. Rev. Sci. Eau. 1998, 11, 209-224.

48. Molinier, M.; Barilly, A.; Gathelier, R.; Thébé, B. Note Hydrologique sur Les Rivières Mary et Gamboma; ORSTOM: Brazzaville, Republic of the Congo, 1974.

49. Minitab. Available online: http://www.minitab.com/fr-fr/products/minitab/free-trial/ (accessed on 27 September 2019).

50. Moatar, F.; Birgand, F.; Meybeck, M.; Faucheux, C.; Raymond, S. Incertitudes sur les métriques de qualité des cours d'eau (médianes et quantiles de concentrations, flux, cas des nutriments évaluées à partir de suivis discrets). Houil. Blanc. 2009, 3, 68-76. [CrossRef]

51. Orange, D. Hydroclimatologie du Fouta Djalon et dynamique actuelle d'un vieux paysage latéritique (Afrique de l'Ouest). Sci. Géol. 1992, 93, 206. 
52. Butturini, A.; Gallart, F.; Latron, J.; Vazquez, E.; Sabater, F. Cross-site comparison of variability of DOC and nitrate $\mathrm{c}-\mathrm{q}$ hysteresis during the autumn-winter period in three Mediterranean headwater streams: A synthetic approach. Biogeochemistry 2006, 77, 327-349. [CrossRef]

53. Butturini, A.; Alvarez, M.; Bernal, S.; Vazquez, E.; Sabater, F. Diversity and temporal sequences of forms of DOC and $\mathrm{NO}_{3}$-discharge responses in an intermittent stream: Predictable or random succession? J. Geophys. Res. 2008, 113, 1-10. [CrossRef]

54. Algharib, I. Apport des Isotopes a vie Moyenne de L'uranium et du Thorium, 210Pb et 10Be Dans L'étude de L'érosion Chimique et Physique de Deux Grands Bassins: Amazone et Congo. Ph.D. Thesis, Nice Sophia Antipolis University, Nice, France, 1992.

55. Summerfield, M.A.; Hulton, N.J. Natural controls of fluvial denudation rates in major world drainage basins. J. Geophys. Res. Solid Earth 1994, 99, 13871-13883. [CrossRef]

56. Degens, E.T.; Kempe, S.; Richey, J.E. Biogeochemistry of Major World Rivers, SCOPE Report 42; John Wiley \& Sons: Chichester, UK, 1991.

57. Dang, T.H.; Coynel, A.; Orange, D.; Blanc, G.; Etcheber, H.; Le, L.A. Long-term monitoring (1960-2008) of the river-sediment transport in the Red River Watershed (Vietnam): Temporal variability and dam-reservoir impact. Sci. Total Environ. 2010, 408, 4654-4664. [CrossRef] [PubMed]

58. Cadée, G.C. Particulate and dissolved organic matter and chlorophyll A in the Zaire River, estuary and plume. Neth. J. Sea Res. 1984, 17, 426-440. [CrossRef]

59. Orange, D. Transports de matières dans un bassin fluvial tropical humide en zone de forêt: L'Uélé au Zaïre. Sci. Géol. Bull. 1996, 49, 71-88.

60. Clerfayt, A. Composition des eaux de rivières du Congo - Influence des Facteurs Géologiques et Climatiques. In Centre Belge d'étude et de Documentation des Eaux; CEBEDEAU: Liège, Belgium, 1956; Volume 31, pp. $26-31$.

61. Nguimalet, C.; Orange, D. Hydroclimatic variabilities in Tomi at Sibut, Gribingui at Kaga-Bandoro and Fafa at Bouca basins, Central-north and central-south of Central African Republic. In Proceedings of the 8th Global FRIEND-Water Conference: Hydrological Processes and Water Security in a Changing World, Beijing, China, 6-9 November 2018.

62. Espinoza Villar, R.; Martinez, J.M.; Guyot, J.L.; Fraizy, P.; Armijos, E.; Crave, A.; Bazan, H.; Vauchel, P.; Lavado, $\mathrm{W}$. The integration of field measurements and satellite observations to determine river solid loads in poorly monitored basins. J. Hydrol. 2012, 444, 221-228. [CrossRef]

63. Espinoza Villar, R.; Martinez, J.M.; Le Texier, M.; Guyot, J.L.; Fraizy, P.; Meneses, P.R.; Oliveira de, E. A study of sediment transport in the Madeira River, Brazil, using MODIS remote-sensing images. J. South Am. Earth Sci. 2012, 44, 45-54. [CrossRef]

64. Yepez, S.; Laraque, A.; Martinez, J.M.; De Sa, J.; Carrera, J.M.; Castellanos, B.; Gallay, M.; Lopez, J.L. Retrieval of suspended sediment concentrations using landsat-8 OLI satellite images in the Orinoco River (Venezuela). C. R. Geosci. 2018, 350, 20-30. [CrossRef]

65. Gallay, M.; Martinez, J.M.; Mora, A.; Castellano, B.; Yepez, S.; Cochonneau, G.; Alfonso, J.A.; Carrera, J.M.; Lopez, J.L.; Laraque, A. Assessing Orinoco river sediment discharge trend using MODIS satellite images. J. South Am. Earth Sci. 2019, 91, 320-331. [CrossRef]

(C) 2020 by the authors. Licensee MDPI, Basel, Switzerland. This article is an open access article distributed under the terms and conditions of the Creative Commons Attribution (CC BY) license (http://creativecommons.org/licenses/by/4.0/). 